\title{
Joint Torts and Several Liability
}

"Joint tort-feasor" is one of those unhappy phrases of indeterminate meaning, whose repetition has done so much to befog the law. Nobody knows what exactly is a joint tort. It has been said" that "no comprehensive general rule can be fornulated which will harmonize all the authorities." Various tests of "jointness" have been proposed: the identity of a cause of action against each of two or more defendants; ${ }^{2}$ the existence of a like, or common duty; ${ }^{3}$ whether the same evidence will support an action against each; ${ }^{4}$ the single, indivisible nature of the injury to the plaintiff; ${ }^{5}$ identity of the facts as to time, place and result ${ }^{6}$ whether the injury is direct and immediate, rather than consequential $;{ }^{7}$ responsibility of the defendants for the same injuria, as distinguished from the same damnum. ${ }^{8}$ An examination of the inultitude of cases ${ }^{9}$ leads to the conclusion that "joint tort-feasor" means radically different things to different courts, and often to the same court; that much of the existing confusion is due to an entire failure to distinguish the different senses in which the term is used; and that the separate problems of joinder of parties in the same action, as a matter of procedure, and the substantive liability of two or more defendants for the saine result, require separate consideration, and have very little in common.

A "joint tort" has siguificance only in so far as it leads to soine definite result. Before making any attempt to classify fact situations, it is necessary to determine what is ineant by "joint" in terms of procedure. Once a tort is considered joint, the legal consequences which follow are more or

\footnotetext{
1 CoOLEY, TORTs (4th ed. 1932) § 86, p. 276.

2 Clerk \& LINDSEIL, Torts (8th ed. 1929) 58.

3 COOLEY, op. cit. supra note 1 , \$ 86, p. 277.

4 Bowen, L. J., in Brunsden v. Humphrey (1884) 14 Q.B.D. 141, at 147.

5 Cooley, op. cit. supra note 1, § 86, p. 278; Flaherty v. Minneapolis \& St. Louis
} Ry Co. (1888) 39 Minn. 328, 40 N. W. 160, 1 L. R. A. 680.

6 Petcoff v. St. Paul City Ry. Co. (1913) 124 Minn. 531, 144 N. W. 474.

${ }^{7}$ Farley v. Crystal Coal \& Coke Co. (1920) 85 W. Va. 595, 102 S. E. 265, 9 A. L. R. 933.

8 Scrutton, L. J., in The Koursk [1924] P. 140.

9 Cases are collected in extensive, and bewildering, annotations in (1920) 9 A.L. R. 939 ; (1925) 35 A.L. R. 409 ; (1934) 91 A.L. R. 759 (acts of independent tort-feasors, each of which alone tends to produce some damage); (1926) 41 A. L.R. 1223 ; (1935) 94 A. L. R. 539 (joinder in one action); (1935) 98 A. L. R. 1057 (jomder of inaster and servant) ; (1927) 50 A. L.R. 361 (two or more persons guilty of similar acts, one of which alone caused the injury); (1922) 16 A.L.R. 465 ; (1929) 62 A. L. R. 1425 (jomt liability of automobile drivers for imjury to third person); (1927) 50 A.I. R. 1106; (1930) 66 A. L. R. 206 (release of one as affecting others); (1923) 27 A. L. R. 805; (1930) 65 A. L. R. 1057 (payment of judgment against one as releasing others); (1925) 34 A. L. R. 345 (joint liability for slander); (1925) 39 A.L.R. 908 (pollution of streams); (1935) 98 A. L. R. 1057 (joint liability of master and servant); (1933) 85 A. L. R. 1095 (right to contribution as affected by settlement with one tort-feasor). 
less well defined; but the rules which have developed have no common historical basis, and are not necessarily connected or related.

The consequences of a "joint tort" are as follows:

1. Joinder of defendants in the same action. Joint tort-feasors may be joined as defendants in the same action at law. The common law rules as to joinder were extremely strict. The earliest cases ${ }^{10}$ in which such joinder was permitted were cases of joint trespass, in which the defendants acted in concert. There was a common purpose, with mutual aid in carrying it out; in short, there was a joint enterprise, so that "all coming to do an unlawful act, and of one party, the act of one is the act of all of the same party being present." 11 Each was therefore liable for the entire damage, although one might have battered the plaintiff, while another imprisoned him, and a third stole his silver buttons. ${ }^{12}$ The jury would not be permitted to apportion the damages. ${ }^{13}$ Given the concert of action and joint responsibility, the identity of the cause of action against each defendant was clear. The defendants might be sued severally, but the plaintiff might have but one judgment, because he had but one cause of action. ${ }^{14}$

Where the defendants did not act in concert, the English courts refused to allow joinder, even though the defendants had done acts identical in character, which had combined in their effect to cause a single, more or less indivisible injury to the plaintiff. Two persons who had uttered the same slanderous words could not be joined, ${ }^{15}$ nor could successive converters of the same property. ${ }^{16} \mathrm{~A}$ master and his servant could be sued together, where the master was liable for the acts of the servant under the doctrine of respondeat superior; but here it is obvious that each is held responsible for the same act. ${ }^{17}$ Without such joint responsibility for one act, the English cases have held quite consistently that there can be no common law joinder, even though the result caused by two defendants is single, and cannot be apportioned. ${ }^{18}$

10 Y. B. 30 Edw. I 106 (Rolls. Ser. 1302) ; Crane and Hill v. Hummerstone (1606) Cro. Jac. 118; Sir John Heydon's Case (1613) 11 Co. Rep. 5 ; Austen v. Willward (1694) Cro. Eliz.

11 Sir John Heydon's Case, supra note 10 , at 6 .

12 Smithson v. Garth (1691) 3 Lev. 324; Clark v. Newsam and Edwards (1847) 1 Exch. 131; cf. Sir Charles Stanley's Case (1663) Kel. 86.

13 Austen v. Willward, supra note 10; Crane and Hill v. Hummerstone, supra note 10; Sir John Heydon's Case, supra note 10; Matthews v. Coal (1615) Cro. Jac. 384 ; cf. Fill v. Goodchild (1771) 5 Burr. 2790.

14 Brown v. Wootton (1600) Cro. Jac. 73; Barlye v. Martin (1647) Sty. 20; Sutton v. Clarke (1815) 6 Taunt. 29; Brinsmead v. Harrison (1872) L. R. 7 C. P. 547.

15 Chamberlain v. White and Goodwin (1617) Cro. Jac. 647.

16 Nicoll v. Glennie (1817) I Maule \& S. 588; cf. Morris v. Rohinson (1824) 3 B. \& C. 196.

${ }^{17} C f$. Wilson v. Tumman (1843) 6 M. \& G. 236.

18 Sadler v. Great Western Ry. Co. [1896] A. C. 450 (two defendants separately 
The early American cases adopted the same position, refusmg to permit joinder of defendants in the absence of some concert of action, or mutual responsibility for the same act. ${ }^{19}$ There were a few exceptions at law, ${ }^{20}$ and a different rule developed in equity in suits for injunction to restrain several parties from contributing to a nuisance, ${ }^{20 \mathrm{a}}$ in which it was not necessary for prevention to ascertain what particular share of damage they had inflicted or threatened to inflict. The attitude of the courts toward joinder of parties was materially altered by the passage of the Field Code in New York in 1848, and similar codes in a majority of the other states. The Code contained a provision, intentionally framed to permit, at law as in equity, the complete settlement of all questions connected with a transaction in a single suit, ${ }^{21}$ to the effect that

"Any person may be made a defendant who has or claims an interest in the controversy adverse to the plaintiff or who is a necessary party to the complete determination or settlement of the questions involved therein."22

blocked the highway with their vans, preventing all access to plaintiff's property); Thompson v. London County Council [1899] 1 Q. B. 840 (one defendant negligently excavated near plaintiff's property, the other left its water main insufficiently stopped, and the property was undermined); The Koursk, supra note 8 (collision between two vessels, injuring a third). In the last named case, the court points out that there has been occasional careless use of the tern "joint tort-feasor" to signify nothing more than concurrent liability for the same loss, particularly in The Devonshire [1912] A. C. 634 and The W. H. No. 1 [1910] P. 199.

A recent case which apparently represents, something of a departure from the established English rule is Arneil v. Peterson [1931] A. C. 560, where the dogs of the two defendants, acting together, attacked plaintiff's sheep. Even here the court is at some pams to stress the fact that the dogs, if not the defendants, were acting in concert.

19 Russell v. Tomlinson and Hawkins (1817) 2 Conn. 206 (dogs killing sheep); Adams v. Hall and Cootwire (1829) 2 Vt. 9, 19 Am. Dec. 690 (same); Van Steenburgh and Gray v. Tobias (1837) 17 Wend. (N. Y.) 562, 31 Am. Dec. 310 (same) ; Buddington v. Shearer (1838) 20 Pick. (Mass.) 477 (same); Hopkins v. Hersey (1841) 20 Me. 449 (successive conversions); Webb v. Cecil and Vaughan (1848) 48 Ky. 198, 48 Am. Dec. 423 (slander of title); Bard and Wenrich v. Yohn (1856) 26 $\mathrm{Pa} .482$ (plaintiff kicked by one defendant's horse and thrown against the other's carriage) ; Little Schuylkill Nav. Co. v. Richard's Adm'r (1868) 57 Pa. 142, 98 Am. Dec. 209 (pollution of stream).

Joinder was of course permitted where the defendants had acted in concert. Halsey v. Woodruff (1830) 9 Pick. (Mass.) 555; Williams v. Sheldon (1833) 10 Wend. (N. Y.) 654; Fuller v. Chamberlain (1846) 11 Metc. (Mass.) 503.

20 One of the outstanding exceptions is Wright v. Cooper (1802) I Ty. (Vt.) 425, where two defendants dammed separate channels of a stream, and flooded plaintiff's land. Joinder was allowed because the damages could not be apportioned. See also Ellis v. Howard (1845) 17 Vt. 330, and Stone v. Dickinson (1862) 5 Allen (Mass.) 29, $81 \mathrm{Am}$. Dec. 727 (officer attaching property or arresting plaintiff on bebalf of different creditors).

20a Woodruff v. North Blooinfield Gravel Mining Co. (C. C. Cal. 1883) 8 Sawy. 628, 16 Fed. 25; Miller v. Highland Ditch Co. (1891) 87 Cal. 430, 25 Pac. 500, 20 Cal. Jur. 321.

21 First Report N. Y. Concm'rs Pz. \& PR. (1848) 124 ; (1924) 33 YaLe L. J. 817.

22 CLARK, Code Pleading (1928) 265 lists the states whose statutes now contain a similar code provision. In addition, New York, New Jersey and California now have still more liberal provisions. Ibid. at 271. 
This provision received, in the main, most uncharitable treatment at the hands of the courts, which tended to follow the earlier precedents, ${ }^{23}$ and to preserve the rule as to concerted action as the test of permissive joinder. ${ }^{24}$ Apart from the familiar inertia of the courts, the chief reason for this failure to accomplish the manifest intention of the code was the retention of the common law notion that the same "cause of action" must affect all of the joined defendants. ${ }^{25}$ Nevertheless, in a number of situations, where the acts of two defendants have combined to produce a single, indivisible result, such as death or a broken leg, the code provision has had its effect, and joinder has been permitted. Thus where the vehicles of two defendants collide and injure the plaintiff, it is held quite uniformly that there may be joinder under the codes. ${ }^{26}$ The same liberality has been extended to other similar situations, where the negligence of both defendants has been necessary to produce a single injury, which from its nature obviously cannot be apportioned. ${ }^{27}$ Some of the code states have

23 See for example Denny v. Correll (1857) 9 Ind. 72 (dogs killing sheep); Cogswell v. Murphy (1877) 46 Iowa 44 (trespassing cattle); Miller v. Highland Ditch Co. (1891) 87 Cal. 430, 25 Pac. 550 (flooding plaintiff's land); Blaisdell v. Stephens (1879) 14 Nev. 17, 33 Am. Rep. 523 (same); Lull v. Fox \& Wis. Imp. Co. (1865) 19 Wis. 100 (same); William Tackaberry Co. v. Sioux City Service Co. (1911) 154 Iowa 358,132 N. W. 945,134 N. W. 1064, 40 L. R. A. (N. s.) 102, Ann. Cas. 1914A, 1276 (same) ; Farley v. Crystal Coal \& Coke Co. (1920) 85 W. Va. 595, 102 S. E. 265, 9 A. L. R. 953 (pollution of stream); Johnson v. City of Fairmont (1933) 188 Minn. 451,247 N. W. 572 (same); Key v. Armour Fertilizer Works (1916) 18 Ga. App. 472,89 S. E. 593 (nuisance due to gases $i m$ the air).

24 CLARK, op. cit. supra note 22 , at 266; and see cases cited supra note 23.

25 Cf. Ader v. Blau (1925) 241 N. Y. 7, 148 N. E. 771, 41 A. L. R. 1216, holding that an original wrongdoer and a surgeon who negligently treated the injured man could not be joimed under the liberal provisions of the New York Civil Practice Act, since there was a separate "cause of action" against each defendant. The case is criticized by Dean Clark in (1925) 35 Yale L. J. 85 ; also in (1925) 25 Col. L. Rev. 975, and (1925) 11 CoRs. L. Q. 113. See Hinton, An American Experiment with the English Rules of Court (1926) 20 Irx. L. Rev. 533.

Many of the codes contain a provision that causes of action, to be joined, must affect all parties to the action. A narrow and restrictive construction of "cause of action" in this provision cuts down materially the possihility of joinder. See CLARK, op. cit. supra note 22 , at $266,302-3$.

26 Colegrove v. New York \& New Haven Co. (1859) 20 N. Y. 492 ; Flaherty v. Minneapolis \& St. Louis Ry. Co. (1888) 39 Minn. 328, 40 N. W. 160, 1 L. R. A. 680; Tompkins v. Clay-Street Hill R. R. Co. (1884) 66 Cal. 163, 4 Pac. 1165; Miller v. Weck (1920) $186 \mathrm{Ky} .552,217$ S. W. 905; Glazener v. Safety Transit Lines (1929) 196 N. C. 504, 146 S. E. 134; Kinley v. Hines (1927) 106 Conn. 82, 137 Atl. 9; McDonald v. Robinson (1929) 207 Iowa 1293, 224 N. W. 820; Peters v. Johnson (1928) 124 Ore. 237, 264 Pac. 459.

27 For example, Carstesen v. Town of Stratford (1896) 67 Conn. 428, 35 Atl. 276 (plaintiff's horse fell successively into excavations left by two defendants, took fright and ran away); Fortmeyer v. National Biscuit Co. (1911) 116 Minn. 158, 133 N. W. 461, 37 L. R. A. (․ S.) 569 (landowner, lessee and city all held properly joined in action to recover for injury due to defective sidewalk); Doyle v. St. Paul Union Depot Co. (1916) 134 Minn. 461, 159 N. W. 1081 (employer and third party 
gone further, and have allowed joinder in situations where the defendants clearly have committed separate, independent torts, resulting in separate injuries, but the difficulty of determining questions of fact, such as the apportioninent of damages, has made joinder "necessary."28 In the remaining common law states, the passage of statutes similar to the code provisions, or precedents from the code states, have led to a similar relaxation of the earlier rule. ${ }^{29}$

It is highly unfortunate that the common law rule as to the identity of a "cause of action" against both defendants should have been carried over to defeat the obvious intent of the code provisions. The advantages of joimder are obvious; ${ }^{30}$ apart from the burden upon the plaintiff and the waste of the court's time in hearing two actions, there are many cases in which substantial justice is more likely to be done if the defendants can be sued together. ${ }^{31}$ The rules against misjoinder are primarily rules of

whose combined negligence injured employee); Campbell Turnpike Road Co. v. Maxfield (Ky. 1906) 91 S. W. 1135 (one defendant cast water on plaintiff's land, the other dammed it on the other side) ; Robertson v. Chicago, B. \& Q. R. R. Co. (1922) 108 Neb. 569, 188 N. W. 190 (railroad and stockyards company each delayed plaintiff's shipment of livestock); Rowe v. Richards (1913) 32 S. D. 66, 142 N. W. 664, L. R. A. 1915E, 1069 (owner negligently constructing building and city negligently permitting it); Schweppe v. Ubl (1914) 97 Neb. 328, 149 N. W. 789 (parade of automobiles frightening plaintiff's horse).

28 For example, Gunder v. Tibbitts (1899) 153 Ind. 591, 55 N. E. 762 (seduction by one defendant, and abortion performed by the other; the court's labored effort to make the two "joint tort-feasors" and hold the doctor liable for the seduction is an excellent illustration of the confusion in which the whole matter is buried); Sherlock v. Manwaren (1924) 208 App. Div. 538, 203 N. Y. Supp. 709 (doctors who successively set plaintiff's shoulder; it is not clear whether the case is overruled by Ader v. Blau, supra note 25).

20 See for example Cudy v. Horn (1881) 46 Mich. 596, 10 N. W. 32, 41 Am. Rep. 178; Carlton v. Boudar (1916) 118 Va. 521, 88 S. E. 174; Matthews v. Delaware, L. \& W. R. R. Co. (1893) 56 N. J. L. 34, 27 At1. 919; Feneff v. Boston \& Maine R. R. (1907) 196 Mass. 575, 82 N. E. 705; Smith v. Yellow Cab Co. (1926) 295 Pa. 229, 132 Atl. 124; Williams v. Kozlowski (1933) $313 \mathrm{~Pa} .219,169$ Atl. 148, 94 A. L. R. 536. 30 See Hinton, loc. cit. supra note 25; (1925) 35 YALE L. J. 85 ; (1925) 25 CoL. L. Rev. 975; (1925) 11 CoRN. L. Q. 113. But compare the court's dissertation on the evils of a liberal rule as to joinder, in Wiest v. City of Pliladelphia (1901) $200 \mathrm{~Pa}$. 148, 49 Atl. 891, 58 L. R. A. 666.

31 The following cases are excellent illustrations of the unsatisfactory situation which may result when joinder is not permitted: McGannon v. Chicago \& N. W. Ry. Co. (1924) 160 Mimn. 143, 199 N. W. 894 (plaintiff, working in a railway sandhouse, developed silicosis through the negligence of successive einployers); Miller v. Highland Ditch Co. (1891) 87 Cal. 430, 25 Pac. 550 (defendants flooding plaintiff's land); Johnson v. City of Fairmont (1933) 188 Minn. 451, 247 N. W. 572 (pollution of streain) ; Albrecht v. St. Hedwig's Roman Catholic Benevolent Soc. (1919) 205 Mich. 395,171 N. W. 461 (successive assaults) ; Ader v. Blau, supra note 25 (original wrongdoer and surgeon negligently treating injured inan); White v. Arizona Eastern R. R. Co. (1924) 26 Ariz. 590, 229 Pac. 101 (employer furnishing plaintiff with defective truck, and railroad running it down at crossing); Salt River Valley Water Users Ass'n. v. Cornum (Ariz. 1937) 63 P. (2d) 639.

Taking McGannon v. Chicago \& N. W. Ry. Co., supra, as an illustration, the 
convenience and expediency, and should be construed in the light of the broader policy agamst multiplicity of suits. ${ }^{32}$ It is still more unfortunate that the wavering uncertainty as to procedural rules should draw in its train an equal confusion as to the substantive liability of defendants.

2. Liability for entire damages. In the earliest cases, ${ }^{33}$ where the defendants acted in concert, "the act of one was the act of all," and each was therefore liable for the entire loss sustained by the plaintiff, even though he might have caused only a part of it. The rule grew out of the common law concept of the unity of the cause of action; the jury could not be permitted to apportion the damages, since there was but one wrong..$^{34}$ Innumerable cases have repeated the statement, that the liability of "joint tort-feasors" is entire, and cannot be divided.

But the common law developed likewise a distinct and altogether unrelated principle: a defendant might be liable for the entire loss sustained by the plaintiff, even though his negligence concurred or combined with that of another to produce the result. Or, as the courts have put it, the defendant is liable for all consequences proximately caused by his wrongful act. The rule was first applied in actions against an individual defendant, where no question of joinder was involved, and where, since there was no concert of action, no joinder would have been possible. Defendant gave a loaded gun to a young servant, who negligently pointed it at plaintiff and shot him; defendant was held liable for the injury. ${ }^{35}$ Defendant left a horse and cart unguarded in the street, and a passing stranger whipped the

following are the more obvious disadvantages of the refusal to permit joinder: (1) in separate suits, it is open to each defendant to prove that the other was solely responsible, or responsible for the greater part of the damage, and so defeat or minimize plaintiff's recovery; (2) it is equally open to the plaintiff to prove that each defendant was solely responsible, or responsible for the greater part of the damage, and so recover excessive compensation; (3) assuming responsibility to be approximately equal, the two verdicts will seldom have any relation to one another; (4) neither defendant may cross-examine the other, or his witnesses, and plaintiff is deprived of the opportunity of cross-examining both defendants in the same action; (5) different witnesses unay be called in the two suits, by the defendants or the plaintiff, or the same witness may tell different stories, so that the full truth is told in neither; (6) time and expense are dotubled.

In soune jurisdictions, all of these difficulties may be obviated by consolidation of the actions, wbich is authorized by statute, usually at the discretion of the court. But even where this is possible, why not perunit joinder in the first instance, and treat it as the equivalent of consolidation? See Snow v. Rudolph (Tex. Civ. App. 1910) 131 S. W. 249; Note (1920) 18 MrcH. L. REv. 708.

32 See Great Southern Life Ins. Co. v. Dolan (Tex. Civ. App. 1922) 239 S. W. 236, rev'd on other grounds in (Tex. 1924) $262 \mathrm{~S}$. W. 475.

33 See cases cited supra notes $12,13$.

${ }^{34}$ See Note (1928) 14 VA. L. REv. 677. An early South Carolina case permitted the jury to apportion damages among joint tort-feasors. White v. McNeily (1784) 1 Bay (S. C.) 11. The case has long since been overruled. National Bank of Savannah v. Southern R. R. (1917) 107 S. C. 28, 91 S. E. 972.

35 Dixon v. Bell (1816) 5 M. \& S. 198. 
horse, which backed into plaintiff's window; defendant was held liable for the damage..$^{36}$ Defendant again left a horse and cart unattended in the street; one boy made the horse move, and another was thrown from the cart and the wheel went over his leg; Lord Denman said that plaintiff might have his action against either the defendant or the other boy, but unquestionably against the defendant. ${ }^{37}$ Defendant went up in a balloon and descended in plaintiff's garden; a crowd collected, and defendant was held liable for the damage which they did to the garden. ${ }^{38}$ In none of these cases was there so much as a suggestion of a joint tort. Apparently liability was based upon an instinctive feeling that defendant was morally responsible for the result, and the evident impossibility of dividing the damages.

Much ink has been shed over proximate cause. It is no part of the purpose of this article to add to the extensive literature on the subject. ${ }^{39}$ Probably no rule can be stated which would cover all of the situations in which a defendant will be liable for an entire loss due in part to the fault of another; but there seems to be general agreement that there will be liability at least where the defendant should reasonably have anticipated the negligence of the other, ${ }^{40}$ or where it is such a normal, or "not highly extraordinary" response to the situation created as to be considered within the scope of the risk created by defendant.4t

In England, such concurrent wrongdoers have not been confused with joint tort-feasors because there could be no joinder in the absence of concerted action. ${ }^{2}$ They might be sued separately; and although each would be liable for the entire loss, 43 the juries were under no compulsion

36 Illidge v. Goodwin (1831) 5 C. \& P. 190.

37 Lynch v. Nurdin (1841) 1 Q. B. 29.

38 Guille v. Swan (1822) 19 Johns. (N. Y.) 381. Cf. Hume v. Oldacre (1816) 1 Stark. 351; King v. Moore (1832) 3 B. \& Ad. 184.

30 See generally Green, Rationale of Proxtmate Cause (1927); Bohlen, The Probable or the Natural Consequence as the Test of Liability in Negligence (1901) 47 Axr. L. Reg. (40 N. S.) 79, 148; Bingham, Some Suggestions Concerning "Legal Cause" at Common Law (1909) 9 CoL. L. Rev. 13, 136; Smith, Legal Cause in Actiouts of Tort (1912) 25 Harv. L. Rev. 103, 223, 303; Terry, Proximate Consequences in the Law of Tort (1914) 28 HaRv. L. Rev. 10; Beale, The Proximate Consequences of an Act (1920) 33 HaRv. L. Rev. 633; Edgerton, Legal Cause (1924) 72 U. of Pa. L. Rev. 211, 343 ; Levitt, Cause, Legal Cause and Proximate Cause (1922) 21 Mrcr. L. Rev. 34, 160; McLaughlin, Proximate Cause (1925) 39 Harv. L. Rev. 149; Carpenter, Workable Rules for Determining Proximate Cause (1932) 20 CaLIF. L. Rev. 229, 396, 471; Peaslee, Multiple Causation and Damage (1934) 47 Harv. L. Rev. 1127; Carpenter, Concurrent Causation (1935) 83 U. of PA. L. Rev. 941; Prosser, The Minnesota Court on Proximate Cause (1936) 21 MINN. L. REv. 19.

40 Carpenter, Workable Rules for Determining Proximate Cause (1932) 20 CaLIF, L. Rev. 471, at 497.

412 Restateatent of the Law of ToRTs (Am. L. Inst. 1934) § 447. Compare $\S \S 439,448$.

42 See notes 16,18 , supra.

43 But compare Morris v. Robinson (1824) 3 B. \& C. 196, where it was intimated, in a case of successive conversions of property, that the jury might consider the possibility of recovery against the second converter, and reduce the damages accordingly in an action against the first. Apparently the suggestion has not been followed. 
to return verdicts for the same amount. Under the more liberal American rules as to jomder, defendants whose negligence has concurred to produce a simgle result have been jomed in one action, and have become at once, by careless usage, "joint tort-feasors." 44 One immediate result has been to confuse joinder of parties with liability for entire damages, and to crystallize the prejudice of the courts against joinder of defendants liable for separate results. Another has been the rigid enforcement of the rule that a verdict for one sum must be returned against all those found liable, without regard to the fact that juries in separate actions would not be so bound. ${ }^{45}$ The unfortunate results of such a rule may be illustrated by a particular case.

Suppose that an automobile negligently driven by defendant $A$ strikes the plaintiff, fractures his skull, and leaves him stunned and helpless on the highway. Shortly thereafter a second automobile, negligently driven by defendant $B$, runs over the plaintiff and breaks his leg. Under the familiar rules of "proximate cause," defendant $A$ should be liable for both the fractured skull and the broken leg, for when the plaintiff was left in the highway it was reasonably to be anticipated that a second car might run hin down. ${ }^{46}$ But defendant $B$ should be liable only for the broken leg, since he had no part in causing the fractured skull, and could not foresee or avoid it. ${ }^{47}$ The fact that the second injury follows closely upon the

44 See Economy Light \& Power Co. v. Hiller (1903) 203 Ill. 518, 68 N. E. 72 (light and telephone wires coming in contact); Glazener v. Safety Transit Lines (1929) 196 N. C. 504, 146 S. E. 134 (vehicle collision); Daly v. Singac Auto Supply Co. (1927) 103 N. J. L. 416, 135 Atl. 868 (one defendant stopped a truck without lights, the other drove into it); De Cock v. O'Connell (1933) 188 Minn. 228, 246 N. W. 885,86 A. L. R. 41 (successive cashers of forged checks); Allison v. Hobbs (1901) 96 Me. 26, 51 Atl. 245 (false arrest on two warrants); Robertson v. Chicago, B. \& Q. R. R. Co. (1922) 108 Neb. 569, 188 N. W. 190 (each defendant delayed plaintiff's livestock shipment) ; Town of Sbaron v. Anahma Realty Corp. (1924) $97 \mathrm{Vt}$. 336, 123 Atl. 192 (ice jain caused by dam and piers of defendants); Tidal Oil Co. v. Pease (1931) 153 Okla. 137, 5 P. (2d) 389 (stock imjured by drinking froin two streams polluted by defendants); Twitchell v. Glenwood-Inglewood Co. (1915) 131 Minn. 375, 155 N. W. 621 (inducing breacb of contract).

45 See Note (1928) 14 VA. L. REv. 677. The length to which the rule is carried is illustrated by Fort Worth \& N. O. R. R. Co. v. Enos (1897) 15 Tex. Civ. App. 673, 39 S. W. 1095, where the court, in a collision case, denied the power of the jury to assess damages severally, and then held that since the acts of the defendants were distinct and separate, and the grounds of defense set up in their separate answers were different, each was entitled to a continuance, and it was error to deny the right to one because it had already been granted at the instance of the other.

46 Adams v. Parish (1920) 189 Ky. 628, 225 S. W. 467; Sawdey v. R. W. Rasmussen Co. (1930) 107 Cal. App. 467, 290 Pac. 684; Morrison v. Medaglia (1934) 287 Mass. 46, 191 N. E. 133; Thornton v. Everoth (1934) 177 Wasb. 1, 30 P. (2d) 951; cf. Wedel v. Johnson (Minn. 1936) 264 N. W. 689.

${ }_{47}^{4}$ La Bella v. Brown (1926) 103 N. J. L. 491, 133 Atl. 82, aff'd, (1927) 135 Atl. 918; Young v. Dille (1923) 127 Wash. 398, 220 Pac. 782. Compare the rule that an original wrongdoer is liable for the results of neghgent treatment of his victim by a 
heels of the first should not make him liable for both, in the absence of some common element of causation or responsibility. 48 Yet it seems reasonably clear that plaintiff should be permitted to join these defendants in one action. ${ }^{49}$ The rule against separate verdicts means either that they must be sued severally, ${ }^{50}$ or that if they are joined each must be held liable for the entire loss. ${ }^{51}$

There is no essential connection between joinder and entire liability. Joinder is a inatter of procedural convenience. Not all of those who are "necessary parties to the complete determination of the questions involved" are liable for the same damages. When defendants who were not joint tort-feasors at common law are joined under the codes, they need not become "joint" for any purpose other than the trial of the case. It is equally unreasonable to deny joinder because there is no entire liability, and to impose such liability because joinder is allowed.

3. Satisfaction of judgment against one releases all. The English rule was that there could be but one judgment on a joint tort. Since the act of each tort-feasor was the act of all, there was but one cause of action, which was "reduced to certainty" or merged in the judgment; and judgment against one, even though unsatisfied, barred any later action against another. ${ }^{52}$ But if the defendants had not acted in concert, the tort was not joint, there were two causes of action, and an unsatisfied judgment against one did not prevent a later action against the other. ${ }^{53}$

At the same time there developed a distinct principle, that the plaintiff was entitled to but one compensation for his loss, and that satisfaction of

physician, Sauter v. New York C. \& H. R. R. R. (1876) 66 N. Y. 50, but the physician is not liable for the damages caused by the original wrongdoer. See Viou v. BrooksScanlon Lumber Co. (1906) 99 Minn. 97, 108 N. W. 891; Pederson v. Eppard (1930) 181 Minn. 47, 231 N. W. 393.

48 "If the acts are not joint in fact, or if the acts do not unite in causing a single injury, they are as widely separated in law by the lapse of mounents as they would be were they separated by the lapse of hours or days." Young v. Dille, supra note 47.

49 Compare the procedure in La Bella v. Brown, stlpra note 47 , where separate actions were consolidated for trial by agreement, but it was held that separate verdicts must be returned. Also the separate verdicts in Young v. Dille, supra note 47; and see Sherlock v. Manwaren (1924) 208 App. Div. 538, 203 N. Y. S. 709.

50 Cf. Albrecht v. St. Hedwig's Roman Catholic Benevolent Soc. (1919) 205 Mich. 395, 171 N. W. 461 (successive assaults) ; McGannon v. Chicago \& N. W. Ry. Co., sulpra note 31 (injury through successive employments); Schafer v. Ostmann (1910) 148 Mo. App. 644, 129 S. W. 63 (simultaneous independent assaults); Barton v. Barton (1906) 119 Mo. App. 507, 94 S. W. 574 (alienation of affections); Ader v. Blau, supra note 25 (original wrongdoer and negligent surgeon).

51 Sawdey v. R. W. Rasmussen Co., supra note 46; Floun v. Birger (Mo. App. 1927) 296 S. W. 203 ; Owens v. Cerullo (N. J. L. 1931) 155 Atl. 759.

52 Brown v. Wootton (1600) Cro. Jac. 73; King v. Hoare (1844) 13 M. \& W. 494 ; Brinsmead v. Harrison (1872) L. R. 7 C. P. 547.

is Morris v. Robinson, supra note 43; Ellis v. Stenning [1932] $2 \mathrm{Ch} .81$; The Koursk, supra note 8. 
his claim, even by a stranger to the action, ${ }^{54}$ would prevent its further enforcement. ${ }^{5 \overline{5}}$ It is obvious that this rule is equitable in its nature, ${ }^{56}$ and that its purpose is to prevent unjust enrichment. It is equally obvious that it applies not only to joint tort-feasors, but also to concurrent wrongdoers not acting in concert, or even to payments made by parties who have no connection with the tort at all..$^{57}$

American courts have tended to confuse the two rules. The first has been generally repudiated in the United States $;^{58}$ the overwhelming weight of authority is that an unsatisfied judgment against one joint tortfeasor does not bar an action against another. ${ }^{50}$ The second has become involved with the muddled concept of "joint tort-feasors;" and while there are cases ${ }^{60}$ holding that payment by one who is not a joint wrongdoer will extinguish the claim, there are others ${ }^{61}$ which refuse to sanction such a rule, and which in effect permit double compensation. The whole problem has been further complicated by the question of releases, which remains to be considered.

4. Release of one releases all. There is a genuine distinction between

54 See Freshwater v. Bulmer Rayon Co. [1933] Ch. 162.

55 Morris v. Robinson, supra note 43; Cooper v. Shepherd (1846) 3 C. B. 266; Ellis v. Stenning, supra note 53.

56 See the statement in Morris v. Robinson, supre note 43, that equity will prevent double satisfaction.

o7 See Miller v. Beck (1899) 108 Iowa 575, 79 N. W. 344.

58 Virginia adopted the English rule in Petticolas v. City of Richmond (1897) 95 Va. 456,28 S. E. 566, but the rule has been changed by statute. Fitzgerald v. Campbell (1921) 131 Va. 486, 109 S. E. 308, 27 A. L. R. 799. An early Rhode Island case, Hunt v. Bates (1862) 7 R. I. 217, 82 Ain. Dec. 592, has been limited strictly to its own facts. Parmenter v. Barstow (1899) 21 R. I. 410, 43 Atl. 1035. Earlier cases holding that suing out execution against one is a bar to action against another were overruled in Cleveland v. Bangor (1895) 87 Me. 259, 32 Atl. 892, 47 Am. St. Rep. 326; Ketelson v. Stilz (1916) 184 Ind. 702, 111 N. E. 423; Verhoeks v. Gillivan (1928) 244 Mich. 367, 221 N. W. 287, 65 A. L. R. 1083.

59 Elliott v. Hayden (1870) 104 Mass. 180; Livingston v. Bishop (1806) 1 Johns. (N. Y.). 290, 3 Am. Dec. 330 ; Lovejoy v. Murray (1866) 3 Wall. 1; Squire v. Ordeman (1909) 194 N. Y. 394, 87 N. E. 435 ; Verhoeks v. Gillivan; Cleveland v. Bangor, both supra note 58; and see cases collected in Note (1923) 27 A. L. R. 805.

60 Coleman v. Gulf Ref. Co. (1926) 172 Ark. 428,289 S. W. 2 ; Muse v. De Vito (1923) 243 Mass. 384, 137 N. E. 730; Carpenter v. W. H. McElwain Co. (1916) 78 N. H. 118, 97 Atl. 560; Young v. Anderson (1921) 33 Idaho 522, 196 Pac. 193; Pederson v. Eppard (1930) 181 Minn. 47, 231 N. W. 393; State ex rel. Cox v. Maryland Elect. Ry. Co. (1915) 126 Md. 300, 95 Atl. 43, L. R. A. 1917A, 270; Chicago Herald Co. v. Bryan (1906) 195 Mo. 574, 92 S. W. 902 ; McCoy v. Louisville \& Nashville R. R. Co. (1905) 146 Ala. 333, 40 So. 106; Hartigan v. Dickson (1900) 81 Minn. 284, 83 N. W. 1091 ; Miller v. Beck (1899) 108 Iowa 575, 79 N. W. 344.

61 Atlantic Dock Co. v. New York (1873) 53 N. Y. 64; Phillips Sheet \& Tin Plate Co. v. Griffith (1918) 98 Ohio St. 73, 120 N. E. 207; Wagner v. Union Stock Yards \& Transit Co. (1891) 41 Ill. App. 408; Grimm v. Globe Printing Co. (Mo. 1921) 232 S. W. 676; Brimer v. Scheibel (1926) 154 Tenn. 253, 290 S. W. 5. 
a satisfaction and a release. A satisfaction is an acceptance of full compensation for the injury; a release is a surrender of the cause of action, which might be gratuitous, or given for inadequate consideration. ${ }^{62} \mathrm{Re}-$ leases at common law were under seal. ${ }^{63} \mathrm{~A}$ release to one of two tortfeasors who had acted in concert necessarily released the other, since there was but one cause of action, which was surrendered. ${ }^{64}$ But as to independent wrongdoers, not acting in concert, who were liable for the same loss, there seems to be no reason to conclude that a release of one would release the others, except in so far as it was based upon actual satisfaction of the claim. ${ }^{65}$

The American courts, doubtless because of the abolition of the seal, ${ }^{66}$ have rather hopelessly confused release with satisfaction. When, in turn, concurrent wrongdoers who have caused the same loss become "joint tortfeasors," the result is chaos. ${ }^{67}$ There is no space here to review the conflicting decisions as to the effect of a release; but there are a substantial number of jurisdictions which hold that a release of one of two concurrent tort-feasors will release the other, ${ }^{68}$ even though it contains an express stipulation that he is not to be released ${ }^{60}$-and this without regard to the

62 "As we have seen, it is entirely immaterial that the one from whom satisfaction was demanded and received was not liable for the entire damage. Indeed, if he were a stranger, and not responsible for any part of it, the rule would be the same. It is important that we distinguish in this connection between what the law denominates a 'release' and what is called a 'satisfaction.' A release may be given, although no part of the damage has been paid, and a technical release to one who is not a joint wrongdoer will not release another, who may have had some connection with this wrong . . . A satisfaction, however, by whomsoever made, if accepted, as such, is a har to further proceedings on the same cause of action." Miller v. Beck, supra note 60. See also Ellis v. Esson (1880) 50 Wis. 138, 6 N. W. 518, 36 Am. Rep. 830; Cleveland, etc. Ry. Co. v. Hillegoss (1908) 171 Ind. 417,86 N. E. 485.

03 Mitchell v. Hawley (1847) 4 Denio (N. Y.) 414, 47 Am. Dec. 260; 3 WILLISTON, CoNTRACTS (1920) 3139-40.

04 Cocke v. Jennor (1614) Hob. 66.

65 The point seems never to have been presented directly to an English court, but the result would seem to follow from the decisions that an unsatisfied judgment is not a bar, because the causes of action are separate. See cases cited in note 53, supra; cf. Freshwater v. Bulmer Rayon Co., supra note 54. See SaLmond, Torts (8th ed. 1934) 82 note $W(3)$.

G6 3 WIILSTON, CONTRACTS (1920) 3140.

67 See 1 CoOLEY, ToRTs (4th ed. 1932) $\$ 83$, pp. 263-267. Cases are collected in Note (1927) 50 A. L. R. 1057.

6s See, for example, Limdsay v. Acme Portland Cement Co. (1922) 220 Mich. 367,190 N. W. 275; Leddy v. Barney (1885) 139 Mass. 394, 2 N. E. 107; Finestone v. Allison Hospital (1932) 106 Fla. 387, 143 So. 251; Tompkins v. Clay-Street Hill R. R. Co., supra note 26.

69 Seither v. Philadelphia Traction Co. (1889) 125 Pa. 397, 17 Atl. 338, 4 L. R. A. 54, 11 Am. St. Rep. 905; Abb v. Northern Pac. Ry. Co. (1902) 28 Wash. 428, 68 Pac. 954, 56 L. R. A. 293, 92 Am. St. Rep. 864 ; McBride v. Scott (1903) 132 Mich. 176, 93 N. W. 243, 61 L. R. A. 445, 102 Am. St. Rep. 416, 1 Ann. Cas. 61; Ducey v. Patterson (1906) 37 Colo. 216, 86 Pac. 109, 9 L. R. A. (N. s.) 1066, 119 Am. St. Rep. 284, 11 
compensation actually received..$^{70}$

It is deplorable that common law notions as to the unity of a cause of action have survived to such an extent. When two defendants in automobiles collide and break the plaimtiff's leg, he may sue thein severally, and recover separate judgments, which may differ in amount. He may elect to enforce either, ${ }^{71}$ or both, and partial satisfaction of one will not extmguish the other. ${ }^{72}$ If he chooses, instead, to take what he can get in the way of part payment from one defendant before suit, his release should not deprive him of his recourse against the other wrongdoer. A few courts have held that a release containing an express reservation of rights against other tort-feasors will not bar action against them, ${ }^{\mathbf{7 3}}$ while others have avoided the issue and arrived at the same result by construing such a release as a inere covenant not to sue. ${ }^{74}$

Ann. Cas. 393; Farmer's Savings Bank v. Aldrich (1911) 153 Iowa 144, 133 N. W. 383; Louisville \& Nashville R. R. Co. v. Allen (1914) 67 Fla. 257, 65 So. 8, L. R. A. 1915C, 20; Moffit v. Endtz (1925) 232 Mich. 2, 204 N. W. 764; Lanasa v. Beggs (1930) 159 Md. 311, 151 Atl. 21; Hawber v. Raley (1928) 92 Cal. App. 701, 268 Pac. 943. These cases in general rely upon two earhier decisions in cases of joint trespass and concerted action, where it was held that the cause of action was surrendered by the release. Ruble v. Turner (1808) 2 Hen. \& Mun. (Va.) 38; Gunther v. Lee (1876) $45 \mathrm{Md}$. 60, 24 Am. Rep. 504.

Two such decisions in New York, Mitchell v. Allen (1881) 25 Hun. (N. Y.) 543 , and Brogan v. Hanan (1900) 55 App. Div. 92, 66 N. Y. S. 1066, would seem to be overruled by Gilbert v. Finch (1903) 173 N. Y. 455,66 N. E. 133, 61 L. R. A. 807,93 Am. St. Rep. 623.

70 The release is "conelusive evidence" of full satisfaction: Abb v. Northern Pac. Ry. Co., supra note 69, even though full coinpensation was not in fact paid. Hawber v. Raley, supra note 69 ; J. E. Pinkhain Lumber Co. v. Woodland State Bank (1930) 156 Wash. 117, 286 Pac. 95.

71 First Nat. Bank v. Indianapolis Piano Mfg. Co. (1873) 45 Ind. 5 ; Irwin v. Jetter Brew. Co. (1917) 101 Neb. 409, 163 N. W. 470; Putncy v. O'Brien (1880) 53 Iowa 117, 4 N. W. 891; Sherman v. Bret (1859) 7 Wis. 139.

72 Meixell v. Kirkpatrick (1883) 29 Kan. 679; McVey v. Mannatt (1890) 80 Iowa 132,45 N. W. 548 ; Lovejoy v. Murray (1865) 3 Wall. 1; Stusser v. Mutual Union Ins. Co. (1923) 127 Wash. 449, 221 Pac. 331; see Boyles v. Knight (1899) 123 Ala. 289, 26 So. 939.

It is held, however, that full satisfaction of the lesser judgment will extinguish the greater, apparently upon the ground that the judgment declares the amount paid to be full compensation. Thomas' Adm'r v. Maysville St. Ry. Co. (1910) $136 \mathrm{Ky}$. 446, 124 S. W. 398, 136 Am. St. Rep. 267; Cox v. Smith (1882) 10 Ore. 418; Larson v. Anderson (1919) 108 Wash. 157, 182 Pac. 957, 6 A. L. R. 621.

73 Gilbert v. Finch (1903) 173 N. Y. 455,66 N. E. 133, 61 L. R. A. 807,93 Am. St. Rep. 623; Dwy v. Connecticut Co. (1915) 89 Conn. 74, 92 Atl. 883; Bloss v. Plynnale (1869) 3 W. Va. 393,100 Am. Dec. 752 ; Baylor University v. Bradshaw (Tex. Civ. App. 1932) 52 S. W. (2d) 1094; Standard Sanitary Mfg. Co. v. Brian's Adm'r (1928) 224 Ky. 419, 6 S. W. (2d) 491; cf. Pogel v. Meilke (1884) 60 Wis. 248, 18 N. W. 927.

74 Duck v. Mayeu [1892] L. R. 2 Q. B. 511; Musolf v. Duluth Edison Elec. Co. (1909) 108 Minn. 369, 122 N. W. 499, 24 L. R. A. (N. S.) 451; Edens v. Fletcher (1908) 79 Kan. 139, 98 Pac. 784, 19 L. R. A. (N. S.) 618; Carey v. Bilby (C. C. A. 8th, 1904) 129 Fed. 203; Snow v. Chandler (1839) 10 N. H. 92, 34 Aun. Dec. 140. 
The position that a release of one necessarily releases all seems most unreasonable. A release of one cause of action is not a release of another independent one. The essential question is whether the plaintiff's claim has been satisfied; ${ }^{7 \bar{x}}$ and this is clearly a matter of the intent of the parties, to be determined in the light of the language of the instrument, the amount paid, and the surrounding circumstances. ${ }^{76}$ The objection that there may be double recovery is meaningless, for the amount paid under the release must be credited pro tanto to the second tort-feasor. ${ }^{77}$ Even as applied to cases of concerted action, ${ }^{78}$ the rule that a release of one releases all seems an antiquated survival of common law procedural notions; it has no justification at all in the case of mere concurrent negligence. ${ }^{78 a}$

5. No contribution between joint tort-feasors. The general rule that there can be no contribution or indemnity between joint tort-feasors ${ }^{79}$ had its origin in 1799 in Merryweather v. Nixan. ${ }^{80}$ There is a very meagre report of the case, but it seems clear that there was an action for conversion, and that the two defendants had acted in concert, since they were joined. One of the two, who had been levied on for the whole judginent, sought "contribution of a moiety" from the other, claiming an implied promise, "as for so much money paid to his use." Lord Kenyon said that there could be no doubt that he should be nonsuit; and that he had never heard of such an action where the former judgment was for a tort.

Various explanations of the decision have been suggested; the court will not lend its aid to one who comes before it with unclean hands; ${ }^{81}$ other potential wrongdoers are to be intimidated by the warning that they enter the wrongful transaction with the risk of bearing all the consequences; ${ }^{82}$

75 JagGard, TorTs (1895) $\$ 117 ; 1$ Coolex, TorTs (4th ed. 1932) $\$ 83$; Notes (1933) 19 VA. L. Rev. 881; (1929) 79 U. of PA. L. Rev. 503.

76 Musolf v. Duluth Edison Elec. Co., supra note 74; Dwy v. Connecticut Co., supra note 73.

77 Pogel v. Meilke, supra note 73; Chicago \& E. I. R. R. Co. v. Hines (1898) 82 IIl. App. 488, aff'd, (1899) 183 Inl. 482, 56 N. E. 177; Dwy v. Connecticut Co., supra note 73.

78 Ruble v. Turner, supra note 69; Gunther v. Lee (1876) 45 Md. 60, 24 Am. Rep. 506.

78a See Legis. (1936) 24 CALIF. L. REv. 551, n32, 711.

70 See generally Reath, Contribution Between Persons Jointly Charged for Negligence (1898) 12 HARv. L. REv. 176; Leflar, Contribution and Indemnity Between Tortfeasors (1932) 81 U oF PA. L. REv. 130; Bohlen, Contribution and Indemnity Between Tort-Feasors (1936) 21 CoRN. L. Q. 552; Notes (1931) 45 HaRv. L. Rev. 349; (1925) 34 Yale L. J. 427, (1931) 16 MINN. L. Rev. 73 ; Legis. (1936) 24 CALIF. I. REv. 546, 702.

80 (1799) 8 T. R. 186.

81 Manowitz v. Kanov (1931) 107 N. J. L. 523, 154 Atl. 326; Owensboro City R. R. Co. v. Louisville, H. \& St. L. Ry. Co. (1915) 165 Ky. 683, 178 S. W. 1043, 1046; Vandiver \& Co. v. Pollak (1895) 107 Ala. 547, 19 So. 180, 54 Am. St. Rep. 118.

82 Thweatt v. Jones (1825) 1 Rand. (Va.) 328, 10 An. Dec. 538; Peck v. Ellis (1816) 2 Johns. Ch. (N. Y.) 131. 
the court will not waste its time with law breakers, at the expense of delay to honest litigants. ${ }^{83}$ It is not likely that any such considerations of policy ever went through Lord Kenyon's head. The ground of the decision would appear to be the simple fact that the parties were joint tort-feasors. Each had taken part voluntarily in the wrongful act; the act of one was the act of the other, and the plaintiff was seeking recovery for what was, in the eyes of the law, entirely his own wrong. 84

Lord Kenyon expressly stated that the decision "would not affect cases of indemnity, where one man employed another to do acts, not unlawful in themselves." 185 Later cases seized upon this limitation, and held that the rule against contribution did not apply unless the plaintiff was a wilful and conscious wrongdoer. ${ }^{86}$ It was not until 1894 that the question was even raised in a case of concurrent negligence, ${ }^{87}$ and the better English view appears to be that the rule does not apply to mere negligence, accident, mistake, or other unintentional breaches of the law. ${ }^{88}$

The early American cases applied the rule against contribution to cases of wilful misconduct, ${ }^{89}$ but refused to recognize it where the tort

83 Avery v. Bank (1909) 221 Mo. 71, 119 S. W. 1106.

84 Reath, loc. cit. supra note 79, has pointed out that at the time of the decision the ineaning of the word "tort" was limited to wilful and intentional wrongs. See also Lord Halsbury's discussion to the same effect in Palmer v. Wick \& Pultneytown Steam Sbipping Co. [1894] A. C. 318, 324.

Compare the case of Everet v. Williams (Ex. 1725) 9 L. Q. Rev. 197 (1893), Costigan, Cases on Legal Etrics (1917) 399, mentioned in Lindlex, Partnersinip (10th ed. 1935) 117, and in 2 Pothier, Obligations (Evans' 2d. Ain. ed. 1839) 6. This was a suit by one highwayman against another for an account of their plunder. The bill was dismissed with costs to be paid by counsel who signed it, plaintiff's solicitors were attached and fimed fifty pounds, and one of them was transported; and plaintiff and defendant were hanged. In short, contribution was not encouraged.

85 Merryweather v. Nixan, supra note 80.

86 In Adamson v. Jarvis (1827) 4 Bing. 66, Best, C. J. allowed indemnity to an auctioneer who had innocently sold goods at the insistence of defendant, and said that "From reason, justice, and sound policy, the rule that wrongdoers cannot have redress or contribution against each other is confined to cases where the person seeking redress must be presuned to have known that he was doing an unlawful act." In Betts v. Gibbins (1834) 2 Ad. \& El. 57, Denman, C. J. said that there was an exception to the rule "where the act is not clearly illegal in itself." To the same effect is Pearson v. Skelton (1836) 1 M. \& W. 504.

87 Palmer v. Wick \& Pultneytown Steam Shipping Co., supra note 84, was a case arising im Scotland, where a workman was killed when one defendant furnished defective tackle and the other negligently used it. Lord Hersehell allowed contribution, saying that the rule of Merryweather v, Nixan did not apply to mere negligence, and in any case it should not be extended to Scots law.

88 SALMOND, TorTs (8th ed. 1934) 86, relying on the cases cited in notes 86 and 87, supra, and on Burrows v. Rhodes [1899] 1 Q. B. 816. On the other hand, in The Englisbman and The Australia [1895] P. 212, Bruce, J., held in a negligence case that there was no right to contribution in the absence of special circumstances raising an implied promise.

80 Peck v. Ellis, supra note 82 (conversion); Arnold v. Clifford (1835) 2 Summ. 238 (libel) ; Miller v. Fenton (1844) 11 Paige (N. Y.) 18 (embezzlement); Hunt 
was a matter of negligence or mistake. ${ }^{90}$ But once the door was thrown open wide to "joint torts," the origin of the rule and the reason for it were. lost to sight, and the overwhelming majority of our courts now refuse to permit contribution even where independent, though concurrent, negligence has contributed to a single loss. ${ }^{91}$ Wisconsm, ${ }^{92}$ Pennsylvania, ${ }^{93}$ Minnesota, ${ }^{94}$ and perhaps Oregon ${ }^{95}$ stand out alone agamst such a result.

There is obvious lack of sense and justice in a rule which permits the entire burden of an accident, for which two defendants were equally, unintentionally to blame, to be shouldered onto one alone, according to the accident of a successful levy of execution, the plaintiff's spite, or his collusion with the other wrongdoer ${ }^{90}$ Half a century of vigorous criticism has had its effect in the introduction of a number of "exceptions" which, to some extent, have restored the original rule. There may be contribution

v. Lane (1857) 9 Ind. 248 (complaimt did not show that the tort was not wilful); Rhea v. White (1859) 3 Head (Tenn.) 121 (no proof that the conversion was not wilful); Spalding v. Oakes (1869) 42 Vt. 343 (keeping ram known to be vicious on premises) ; Atkins v. Johnson (1870) 43 Vt. 78, 5 Am. Rep. 260 (libel); Davis v. Gilhaus (1886) 44 Ohio St. 69 (embezzlement).

90 Thweatt v. Jones, supra note 82 (misdelivery of tobacco by mistake) ; Horbach v. Elder (1851) $18 \mathrm{~Pa} .33$ (partners operating stage line, whose driver negligently injured a passenger); Acheson v. Miller (1853) 2 Ohio St. 203 (levy on goods under mistaken belief that it was lawful); Bailey v. Bussing (1859) 28 Conn. 455 (owner of coach suing negligent driver); Armstrong County v. Clarion County (1870) $66 \mathrm{~Pa} .218$ (neghigent maintenance of a bridge) ; Nickerson v. Wheeler (1875) 118 Mass. 295 (neglect to file corporate certificates). See Reath, Contribution Between Persons Jointly Claarged for Negligence (1899) 12 HARv. L. REv. 176, 180-192.

01 Union Stock Yards Co. v. Chicago, B. \& Q. R. R. Co. (1905) 196 U. S. 217, 2 Ann. Cas. 525; Adams v. White Bus Line (1921) 184 Cal. 710, 195 Pac. 389; Central of Georgia Ry. Co. v. Swift \& Co. (1918) 23 Ga. App. 346, 98 S. E. 256; Illinois Central R. R. Co. v. Louisville Bridge Co. (1916) $171 \mathrm{Ky} .445,188 \mathrm{~S}$. W. 476; Village of Portland v. Citizens Tel. Co. (1919) 206 Mich. 632, 173 N. W. 382; Gregg v. Page Belting Co. (1897) 69 N. H. 247, 46 Atl. 26; Public Service Ry. Co. v. Mateucci (1928) 105 N. J. L. 114, 143 Atl. 221; Doles v. Seaboard Air Line Ry. Co. (1912) 160 N. C. 318 , 75 S. E. 722,42 L. R. A. (N. S.) 67; Royal Indemnity Co. v. Becker (1930) 122 Ohio St. 582, 173 N. E. 194; Cain v. Quannah Light \& Ice Co. (1928) 131 Okla. 25, 267 Pac. 641; Galveston, H. \& S. A. Ry. Co. v. Nass (1900) 94 Tex. 255, 59 S. W. 870; Norfolk \& S. R. R. Co. v. Beskin (1924) 140 Va. 744, 125 S. E. 678; Tacoma v. Bonnell (1911) 65 Wash. 505, 118 Pac. 642, 36 L. R. A. (N. s.) 582, Ann. Cas. 1913B, 934.

92 Ellis v. Chicago \& N. W. Ry. Co. (1918) 167 Wis. 392, 167 N. W. 1048; Mitchell v. Raymond (1923) 181 Wis. 591, 195 N. W. 855; Sattler v. Neiderkorn (1926) 190 Wis. 464, 209 N. W. 607 ; Haines v. Duffy (1931) 206 Wis. 193, 240 N. W. 152.

93 Armstrong County v. Clarion County, supra note 90; Goldman v. MitchellFletcher Co. (1928) 292 Pa. St. 354, 141 Atl. 231.

94 Underwriters at Lloyds v. Smith (1926) $166 \mathrm{Mmn} .388,208 \mathrm{~N}$. W. 13; Duluth, M. \& N. Ry. Co. v. McCarthy (1931) 183 Minn. 414, 236 N. W. 766.

95 See Furbeck v. I. Gevurtz \& Son (1914) 72 Ore. 12, 22, 143 Pac. 654.

96 As an example of such collusion, see Pennsylvania Co. v. Western Pa. Rys. Co. (1924) 110 Ohio St. 516, 144 N. E. 51; also Norfolk S. Ry. Co. v. Beskin (1924) 140 Va. 744,125 S. E. 678. 
or indemnity where one wrongdoer is liable solely by inference of law because of his relation to the other, as where an innocent partner is held responsible for partnership acts. ${ }^{9 \tau}$ Likewise where one is directed or employed by another to do an act not manifestly wrong, which proves to be a violation of the rights of a third party. ${ }^{98}$ Again, where one is under only a secondary duty and the other is primarily responsible, as where a municipal corporation, held liable for failure to keep its streets in safe condition, seeks recovery from the person who caused the condition, ${ }^{90}$ or an owner of property liable for injuries received on it sues the actual wrongdoer who created the hazard. ${ }^{100}$ One held under respondeat superior for the acts of his agent or servant may recover indemnity from the latter. ${ }^{101}$ And there is authority that one whose negligence consisted of mere passive neglect may have contribution from an active wrongdoer. ${ }^{102}$ Dissatisfaction in a dozen states has led finally to the passage of statutes, ${ }^{103}$

07 Farney v. Hauser (1921) 109 Kan. 75; 198 Pac. 178; Estate of Ryan (1914) 157 Wis. 576,147 N. W. 993 , L. R. A. 1917A, 443, Ann. Cas. 1916D, 840; Smith v. Ayrault (1888) 71 Mich. 475,39 N. W. 724,1 L. R. A. 311.

08 Horrabin v. City of Des Moines (1924) 198 Iowa 549, 199 N. W. 988, 38 A. L. R. 554 ; Culmer v. Wilson (1896) 13 Utah 129, 44 Pac. 833, 57 A.n. St. Rep. 713. ${ }^{99}$ Township of Hart v. Noret (1916) 191 Mich 427, 158 N. W. 17, L. R. A. 1916 F, 83 ; Baltimore \& O. R. R. Co. v. Howard County (1910) 113 Md. 404, 77 Atl. 930; Washington Gas Light Co. v. District of Columhia (1895) 161 U. S. 316; City of Wabasha v. Southworth (1893) 54 Minn. 79, 55 N. W. 818; Lowell v. Boston \& Lowell R. R. Co. (1839) 23 Pick. (Mass.) 24, 34 Am. Dec. 33.

100 Gray v. Boston Gas Light Co. (1873) 114 Mass. 149, 19 Am. Rep. 324; Westfield Gas \& Milling Co. v. Noblesville \& E. G. R. Co. (1895) 13 Ind. App. 481, 41 N. E. 955, 55 Am. St. Rep. 244 ; Oceanic Steam Nav. Co. v. Compania Transatlantica Española (1892) 134 N. Y. 461, 31 N. E. 987,30 Am. St. Rep. 685; Churchill v. Holt (1879) 127 Mass. 165, 34 Ain. Rep. 355.

101 Smith v. Foran (1875) 43 Conn. 244; Georgia So. \& Fla. Ry. Co. v. Jossey (1898) 105 Ga. 271, 31 S. E. 179; Costa v. Yoachim (1900) 104 La. 170, 28 So. 992; Grand Trunk Ry. Co. v. Latham (1874) 63 Me. 177; Hill v. Murphy (1912) 212 Mass. 1, 98 N. E. 781; Gaffner v. Johnson (1905) 39 Wash. 437, 81 Pac. 859.

102 Southwestern Bell Tel. Co. v. East Tex. Pub. Serv. Co. (C. C. A. 5th, 1931) 48 F. (2d) 23; Colorado \& Southern Ry. v. Western Light \& Power Co. (1923) 73 Colo. 107, 214 Pac. 30; Chicago Rys. Co. v. R. F. Conway Co. (1920) 219 Ill. App. 220; Astoria v. Astoria \& Columbia River R. R. Co. (1913) 67 Ore. 538, 136 Pac. 645, 49 L. R. A. (N. S.) 404; Chicago \& N. W. Ry. Co. v. Dunn (1882) 59 Iowa 619, 13 N. W. 722.

103 Ga. Code ANN. (Michie, 1926) §§ 4512-13 ("joint trespassers" only); KaN. Rev. Stat. AnN. (1923) $\$ 60-3437$ (procedural statute as to joint judginents); KY. StAT. (Carroll, 1930) \$484a; MD. ANn. Code (Baghy Supp. 1929) art. 50, \$12a; Mich. Comp. Laws (1929) \& 14497 (lihel cases only); Mo. Rev. Stat. (1929) \& 3268; N. M. Stat. Ann. (Courtright, 1929) \$\$76-101; N. Y. Crv. PrAc. Acr (GilhertBliss 1936 Supp.) \$211a; N. C. Code AnN. (1931) \$618; TEx. Rev. Crv. Code (Vernon, 1928) \$2212; VA. CODE ANN. (Michie, 1930) \$5779; W. VA. Code (1931) c. 55, art. $7, \$ 13$.

These statutes are criticized in Gregory, Legislative Loss Distrimution in Negligence Actions (1936), reviewed (1936) 24 CALIF. L. Rev. 612; also Leflar, Contribution and Indemnity Between Tortfeasors (1932) 81 U. of PA. L. REv. 130; Note (1931) 45 HARv. L. REv. 349. 
which to a greater or less extent permit contribution between joint tortfeasors. It seems probable that in due course of time pressure of opinion will compel the abolition of the rule, at least as to all except wilful wrongdoers. ${ }^{104}$

The law lies under the tyranny of words. Is it too much to say that . everybody knows that there should be liberal procedural rules as to the joinder of parties defendant in tort cases, according to convenience; that damages should be apportioned among defendants according to their respective responsibilities; that a plaintiff should not be deeined to surrender his clain without full compensation unless he intends to do so; that those equally responsible for the same loss should bear it equally? Yet all that stands in the way of these results is a body of precedent built up upon the meaning, or lack of meaning, of the single phrase, "joint tortfeasors."

If the foregoing analysis is correct, joinder should be no more than a matter of procedural convenience; release should be no more than a matter of intent; and contribution should be compelled whenever justice demands it. None of these depends upon whether the tort is "joint" or several. There remains the question, what, then, is a "joint tort"? Stripped of these irrelevant complications, the problem may be restated: under what circuinstances will two defendants be liable for the same damages? This, at least, is a question of substantive law. It is possible to attempt some rough classification of the cases, ${ }^{105}$ and to venture one or two conclusions as to the situations which have offered the greatest difficulty. The cases seem to fall naturally into the following groups:

A. Concerted action. It is settled definitely that all who act in concert will be liable for the entire result. ${ }^{106}$ The rule is the same at criminal law. ${ }^{107}$ Those who actively participate in the wrongful act, by cooperation

104 See Legis. (1936) 24 CAIIF. L. REv. 546, 702. The language of many of the statutes is sufficiently broad to permit contribution even between intentional wrongdoers. It has been suggested that these statutes might nevertheless be interpreted to apply only to negligent or unintended torts (1931) 16 CoRN. L. Q. 246.

105 See Notes (1931) 19 CarIF. L. Rev. 630; (1924) 24 'Cor. L. Rev. 891.

106 Clark v. Newsam and Edwards (1847) 1 Exch. 131; Wrabek v. Suchomel (1920) 145 Minn. 468, 177 N. W. 764; Halsey v. Woodruff (1830) 9 Pick. (Mass.) 555; Williams v. Sheldon (1833) 10 Wend. (N. Y.) 654 ; Bunker Hill \& Sullivan Min. Con. Co. v. Polak (C. C. A. 9th, 1925) 7 F. (2d) 583; Price v. Price (1894) 91 Iowa 693,60 N. W. 202,29 L. R. A. 150, 51 Am. St. Rep. 360; Benson v. Ross (1906) 143 Mich. 452, 106 N. W. 1120; Reyher v. Mayne (1932) 90 Colo. 586, 10 P. (2d) 1109; Central of Georgia Ry. Co. v. Brown (1901) 113 Ga. 414, 38 S. E. 989, 84 Am. St. Rep. 250; Oliver v. Miles (1926) 144 Miss. 852, 110 So. 666; Bobich v. Dackow (1929) $229 \mathrm{Ky} .830,18 \mathrm{~S}$. W. (2d) 280 . See also the amusing opinion of Minturn, J., in Tricoli v. Centalanza (1924) 100 N. J. L. 231, 126 Atl. 214.

107 Sir Charles Stanley's Case (1663) Kel. 86; State v. Newberg (1929) 129 Or. 564, 278 Pac. 568. 
or request, ${ }^{108}$ or who lend aid, encouragement or countenance to the wrongdoer, ${ }^{109}$ or approval to his acts done for their benefit, ${ }^{110}$ are equally liable with him. Express agreement is not necessary; all that is required is that there shall be a common design or understanding. "111 Such wrongdoers were "jomt tort-feasors" at common law, and the cases present no difficulty. There are occasional statements ${ }^{112}$ that mere knowledge by each party of what the other is doing is sufficient "concert" to make each liable for the acts of the other. Such knowledge undoubtedly may be important in determining whether either defendant is at fault at all; ${ }^{113}$ but unless the circumstances are such as to show a tacit understanding, it would seem that there can be knowledge without concerted action. ${ }^{114}$

B. Vicarious liability. The liability of a master for the acts of his servant, or that of a principal for his agent, within the scope of the employment or agency, extends of course to the entire result, and in this sense the tort is clearly a "joint" one. There has been a controversy over the procedural question of joinder in one action, some courts holding that there can be no joinder unless the act was authorized or commanded, upon the theory that the liability of the servant is direct and positive, while that of the master is merely, imputed under respondeat superior. ${ }^{115}$ The distinction is highly artificial, and there seems to be little justification for it at common law. ${ }^{116}$ The weight of authority permits such joinder. ${ }^{117}$ Likewise a

108 Judson v. Cook (1852) 11 Barb. (N. X.) 642; Chicago, K. \& W. R. R. Co. v. Watkins (1890) 43 Kan. 50, 22 Pac. 985; Sourbier v. Brown (1919) 188 Ind. 584, 123 N. E. 802.

109 Daingerfield v. Thompson (1880) 33 Grat. (Va.) 136; Hilmes v. Stroebel (1883) 59 Wis. 74, 17 N. W. 539. As to what is meant by "encouragement," see Bird v. Lynn (1850) 10 B. Mon. (Ky.) 422; Brown v. Perkins (1861) 1 Allen (Mass.) 89. 110 Stull v. Porter (1921) 100 Ore. 514, 196 Pac. 1116; Weinberg Co. v. Bixby (1921) 185 Cal. 87, 196 Pac. 25.

111 Reader v. Ottis (1920) 147 Minn. 385, 180 N. W. 117, 16 A. L. R. 463; Hanrahan v. Cochran (1896) 12 App. Div. 91, 42 N. X. S. 1031; Stapler v. Parler (1925) 212 Ala. 644, 103 So. 573; Troop v. Dew (1921) 150 Ark. 560, 234 S. W. 992 ; Daggy v. Miller (1917) 180 Iowa 1146, 162 N. W. 854; Larimer \& Weld Irr. Co. v. Walker (1918) 65 Colo. 320, 176 Pac. 282; Brooke v. Bool [1928] 2 K. B. 578. See also the cases of damage done by animals kept in a common herd, infra note 153.

112 Moses v. Town of Morgantown (1926) 192 N. C. 102, 133 S. E. 421; sec Sloggy v. Dilworth (1888) 38 Minn. 179, 36 N. W. 451, 8 Am. St. Rep. 656; Bowman v. Humphrey (1904) 124 Iowa 744, 100 N. W. 854.

113 See infra, text at note 171.

114 The point is not mentioned in a large number of pollution cases, where it seems evident that each defendant must have known of the activities of the others. See infra, note 154, and particularly Johnson v. City of Fairmont (1933) 188 Minn. 451,247 N.W. 572.

115 Mulchey v. Methodist Rebigious Soc. (1878) 125 Mass. 487; Helms v. Northern Pac. Ry. Co. (C. C. Minn., 1903) 120 Fed. 389; Hobbs v. Hurley (1918) 117 Me. 449, 104 Atl. 815 ; French v. Central Const. Co. (1907) 76 Ohio St. 509,81 N. E. 751,12 L. R. A. (N. S.) 669.

116 Cf. Salmond, Torts (8th ed. 1934) 79; Clerk \& Lindseit, Torts (8th ed. 1929) 58.

117 Mayberry v. Northern Pac. Ry. Co. (1907) 100 Minn. 79, 110 N. W. 356, 12 L. R. A. (N. S.) 675,10 Ann. Cas. 754; Phelps v. Wait, (1864) 30 N. Y. 78; Schumpert v. Southern Ry. Co. (1903) 65 S. C. 332, 43 S. E. 813, 95 Am. St. Rep. 802; 
partner is jointly liable for the acts of other partners in the transaction of partnership business. ${ }^{118}$

C. Common Duty. Two defendants inay be under a precisely similar duty to use care to prevent a particular occurrence. The most obvious illustration is the case of the fall of a party wall, through the negligence of adjoining landowners. In such a case each is, of course, liable for the entire damage, and it is commonly held that they may be joined in one action. ${ }^{119}$ The cases shade off into those discussed under the next succeeding head, and there has been much poimtless argument as to whether, in a given case, the duties are sufficiently identical to permit joinderwhether, for example, a city and a property owner responsible for the condition of a sidewalk may be sued together. ${ }^{120}$ The possibility that one defendant may be entitled to indemnity from the other has been given as a reason for refusing to allow joinder. ${ }^{121}$ But if joinder is merely a matter of procedural convenience, there would seein to be no reason for holding it a bar to adjustment of the rights of the defendants among themselves. ${ }^{122}$ The weight of authority probably permits joinder in such cases. ${ }^{123}$

Illinois Cent. R. R. Co. v. Hutchins (1905) $121 \mathrm{Ky} .526,89$ S. W. 530; Verlinda v. Stone \& W. Eng. Corp. (1911) 44 Mont. 223, 119 Pac. 573; Allen v. Trester (1924) 112 Neb. 515, 199 N. W. 841 ; Whalen v. Pennsylvania R. R. Co. (1906) 73 N. J. L. 192, 63 Atl. 993. Cases are collected in Note (1935) 98 A. L. R. 1057.

118 Tucker v. Cole (1882) 54 Wis. 539, 11 N. W. 703.

110 Johnson v. Chapman (1897) 43 W. Va. 639 , 28 S. E. 744 ; Klauder v. McGrath (1860) 35 Pa. 128, 78 Am. Dec. 329; Siminons v. Everson (1891) 124 N. Y. 319, 26 N. E. 911, 21 Am. St. Rep. 676. Compare Lindsay v. Acme Cement Plaster Co. (1922) 220 Mich 367,190 N. W. 275 (two defendants under a duty to keep track in repair); Wisconsin Cent. R. R. Co. v. Ross (1892) 142 III. 9, 31 N. E. 412 (saune) ; Doeg v. Cook (1899) 126 Cal. 213, 58 Pac. 707, 77 Am. St. Rep. 171 (town marshall, town trustees and surety sued together for defective highway); Walton, Witten \& Graham Co. v. Miller's Adm'x (1909) 109 Va. 210, 63 S. E. 458 (employer and contractor both under duty to warn employee as to blasting); Nelson v. Illinois Cent. R. R. Co. (1910) 96 Miss. 373, 53 So. 619 (railroad and Pullman company liable for loss of baggage).

120 Joinder was held improper in Bennett v. Fifield (1880) 13 R. I. 139, 43 Am. Rep. 17; Morris v. Woodbury (1897) 57 Ohio St. 330, 48 N. E. 1097; Dutton v. Borough of Landsdowne (1901) $198 \mathrm{~Pa}$. 563, 48 Atl. 494; Wiest v. City of Philadelphia (1901) $200 \mathrm{~Pa}$. St. 148, 49 Atl. 891, $58 \mathrm{~L}$. R. A. 666; Trowbridge v. Forepaugh (1869) 14 Minn. 133 (overruled in Fortmeyer v. National Biscuit Co. (1911) 116 Minn. 158, 133 N. W. 461, 37 L. R. A. (N. s.) 569.

Compare Cole v. Lippitt (1900) 22 R. I. 31, 46 Atl. 43 (owner causing bullding to be erected on improper plans, architect failing to supervise, and contractor negligently doing work may not be joined).

121 See the first four cases cited in note 120, supra.

122 Schneider v. City Cormcil of Augusta (1903) 118 Ga. 610, 45 S. E. 459 ; cf. Ankeny v. Moffett (1887) 37 Minn. 109, 33 N. W. 320.

123 Fortmeyer v. National Biscuit Co., supra note 120; Scearce v. Mayor and Council of Gainesville (1925) 33 Ga. App. 411, 126 S. E. 883; Williams v. Kozlowski (1933) $313 \mathrm{~Pa} .219,169$ Atl. 148 (under broader statute); Rowe v. Richards (1913) 32 S. D. 66, 142 N. W. 664, L. R. A. 1915E 1069. 
D. Concurrent causation of a single, indivisible result, which neither would have caused alone. Where the acts of two defendants combine to produce a single result, which is incapable of being divided or apportioned - such as the death of the plaintiff-each may be the proximate cause of the loss, and each may be held liable for the entire damage. A common case is that of two vehicles which collide and injure a third person. ${ }^{124}$ The duties which are owed to the plaintiff by the defendants are separate, and may not be similar in character or scope, ${ }^{125}$ but by far the greater number of courts now permit joinder in one action. ${ }^{120}$

Entire liability in these cases rests upon the obvious fact that each defendant is responsible for the loss, and the absence of any logical basis for apportionment. It is not necessary that the misconduct of the defendants be simultaneous, or that it operate simultaneously to produce the result; one defendant may create a situation, harmless in itself, upon which the other may act to cause injury. ${ }^{127}$ One may leave combustible

${ }^{124}$ See cases cited in note 26, supra, also Chiles v. Rohl (1924) 47 S. D. 580, 201 N. W. 154.

125 In Carlton v. Boudar (1916) 118 Va. 521,88 S. E. 174, the court held this to be immaterial.

126 See cases cited in notes 26, 27, 44, supra. Also Slater v. Mersereau (1876) 64 N. Y. 138 (defendants flooding plaintiff's property from separate sources); Folsom v. Apple River Log-Driving Co. (1877) 41 Wis. 602 (dan and bridge causing a flood); Brown v. Coxe Bros. \& Co. (C. C. Wis. 1896) 75 Fed. 689 (employer not furnishing safe place to work and third party negligently operating coal bucket); Washington \& Georgetown R. R. Co. v. Hickey (1897) 166 U. S. 521, 17 Sup. Ct. 661, 41 L. Ed. 1101 (horse car driven onto railway tracks with negligent operation of crossing gates); Northrup v. Eakes (1918) 72 Okla. 66, 178 Pac. 266 (defendants poured crude oil into the same creek, which was ignited and burned plaintiff's premises); Drown v. New England Tel. \& Tel. Co. (1907) 80 Vt. 1, 66 Atl. 801 (light wires and telephone wires crossed); Louisville \& Nashville R. R. Co. v. Allen (1914) 67 Fla. 257, 65 So. 8, L. R. A. 1915 C 20 (trolley company and railroad company not removing trolley wire over railroad track); Ramsey v. Carolina-Tennessee Power Co. (1928) 195 N. C. 788 , 143 S. E. 861 (railway shunting cars whicb struck negligently maintained power line pole).

Contra: Bard and Wenrich v. Yohn (1856) $26 \mathrm{~Pa}$. 482; Howard v. Union Traction Co. (1900) $195 \mathrm{~Pa} .391,45$ Atl. 1076; White v. Arizona Eastern R. R. Co. (1924) 26 Ariz. 590, 229 Pac. 101; Thompson v. London County Council [1899] 1 Q. B. 840; The Koursk, supra note 8 .

$12 \pi$ Johnson v. Northwesteru Tel. Exch. Co. (1892) 48 Minn. 433, 51 N. W. 225 (one defendant maintained an unsafe pole, the other cut the guy wire); Barues v. Masterson (1899) 38 App. Div. 612, 56 N. Y. S. 939 (defendants successively deposited sand against plaintiff's wall, which collapsed); Straubal v. Asiatic S. S. Co. (1906) 48 Or. 100, 85 Pac. 230 (one defendant furnished an unseaworthy barge, the other neghigently loaded it); Pacific Tel. \& Tel. Co. v. Parmenter (C. C. A. 9th, 1909) 170 Fed. 140 (one defendant maintained a rotten pole, the other felled a tree against the guy wires); Reynolds v. Metropohtan Street Ry. Co. (Mo. App. 1914) $168 \mathrm{~S}$. W. 221 (one defendant left a hole in the street, and plaintiff stepped into it getting off the other's street car); Kaszovitz v. Trustees of Sailors' Snug Harbor (1926) 127 Misc. 818,216 N. Y. S. 745 (one defendant had a defective ceiling, the other let water seep through it). 
material, and the other set it afire; ${ }^{128}$ one may leave a hole in the street, and the other drive into it. ${ }^{129}$ The first defendant remains the proximate cause of the injury, so long as the intervention of the second is a foreseeable, or normal, "not extraordinary" consequence, which fairly may be said to lie within the scope of the risk created. ${ }^{130}$

E. Concurrent causation of a single, indivisible result, which either alone would have caused. A somewhat more difficult problem is presented if the act of either defendant, standing alone, would have produced the particular result without the other. Two defendants, at the same time, pass the plaintiff on motorcycles, frightening his horse, which runs away and injures him; either alone would have caused the same result. ${ }^{131}$ Fires set by two defendants merge and burn over plaintiff's property; either alone would have done it. ${ }^{132}$ Two packages of explosives go off together, and destroy plaintiff's property, which either alone would have destroyed. ${ }^{133} B$ stabs $A$ with a knife, and $C$ fractures $A$ 's skull with a rock; 488.

128 Johnson v. Chicago, M. \& St. P. Ry. Co. (1883) 31 Minn. 57, 16 N. W.

129 Tobin v. City of Seattle (1923) 127 Wash. 664, 221 Pac. 583.

130 Carpenter, Workable Rules for Determining Proximate Cause (1932) 20 Carm. L. Rev. 471, 495-520; McLaugblin, Proximate Cause (1925) 39 Harv. L. Rev. 149.

The Restatement has taken the position that the intervening cause need not be "foreseeable" to the defendant, but that it is sufficient if, looking back at the event, it is to be regarded as "normal" or "not extraordinary." 2 RESTATEMENT or THE LAW OF TORTS (Am. L. Inst. 1934) § 447; cf. Bohlen, Review of Harper, Law of Torts (1934) 47 HARv. L. REv. 556, 557. The distinction is a subtle one, and seems to be entirely a matter of definition. As the term "foreseeable" has been used by the courts, it would seem to include all risks normally incident to a dangerous situation created by the defendant. What is meant in each case is that the intervention shall be justly attachable to the original risk.

131 Corey v. Havener (1902) 182 Mass. 250, 65 N. E. 69.

132 McClellan v. St. Paul, M. \& M. Ry. Co. (1894) 58 Minn. 104,59 N. W. 978; Cook v. Minneapolis, St. P. \& S. S. M. Ry. Co. (1898) 98 Wis. 624,74 N. W. 561; Anderson v. Minneapolis, St. P. \& S. S. M. Ry. Co. (1920) 146 Minn. 430, 179 N. W. 45; Miller v. Northern Pac. Ry. Co. (1913) 24 Idaho 567, 135 Pac. 845; Seckerson v. Sinclair (1913) 24 N. D. 625,140 N. W. 239; Kingston v. Chicago \& N. W. Ry. Co. (1927) 191 Wis. 610, 211 N. W. 913.

The Wisconsin court in the Cook case drew a fine distinction between the case of two fires, both of responsible origin, and the case where one fire has no responsible source, holding that in the latter case there is no liability upon the responsible defendant. Later, in the Kingston case, the court more or less nullified the effect of the rule by holding that the burden was upon the defendant to prove the natural origin of the other fire. The distinction made in the Cook case was approved in Miller v. Northern Pac. Ry., supra, but was rejected in Anderson v. Minneapolis, St. P. \& S. S. M. Ry. Co., supra. Peaslee, Multiple Causation and Damage (1934) 47 HARv. L. REv. 1127, approves the Cook case upon the ground that potential destruction by the fire of innocent origin has removed all value from the property. To the contrary, see Carpenter, Concurrent Causation (1935) 83 U. oF PA. L. REV. 941. Discussion of the point is beyond the scope of this article.

133 Oulighan v. Butler (1905) 189 Mass. 287,75 N. E. 726. Cf. Boston \& Albany R. R. Co. v. Shanly (1871) 107 Mass. 568; Orton v. Virginia Carolina Cbem. Co. (1918) 142 La. 790, 77 So. 632. 
either wound would be fatal, and $A$ dies of the effects of both. ${ }^{134}$ In such cases it is clear that each defendant is in fact responsible for the single result, which cannot be apportioned; it is also clear that neither can be absolved from liability upon the ground that the injury would have happened without him, or there will be no recovery at all. Each defendant must be liable if his act was a material and substantial factor ${ }^{135}$ in producing the result, even though he was not essential to it. Upon this the courts have generally agreed. Where the point has arisen, it has been held that the parties may be joined in one action. ${ }^{136}$ The problem is presented in slightly different form in cases where several independent writs are executed by the same officer, who levies upon property or arrests the plaintiff on behalf of defendants not acting in concert. The weight of authority is that such defendants may be joined, and each is liable for the entire damage. ${ }^{137}$

F. Successive injuries. The injuries inflicted may be severable in point of time. If two defendants, independently operating the same plant, pollute a stream over successive periods, it is clear that each has caused separate damage, limited in time, and that neither has any responsibility for the acts of the other. ${ }^{138}$ The same may be true where a workman's health is impaired through the negligence of successive employers, ${ }^{130}$ or where there are successive assaults upon the plaintiff. ${ }^{140}$ In such cases there is available a logical basis for apportionment of the loss, which is lacking in the cases hitherto considered. It is possible to say, in theory at least, where one defendant's wrong left off and the other's began. As a practical matter, it may be difficult or impossible to produce satisfactory evidence as to the extent of the damages caused by each; but this is no

134 Wilson v. State (Tex. Cr. App. 1893) 11 S. W. 409; Thompson v. Louisville \& Nashville R. R. Co. (1890) 91 Ala. 496, 8 So. 406, 11 L. R. A. 146; Pcople v. Lewis (1899) 124 Cal. 551, 57 Pac. 470.

1352 Restatement of the Law of Torts (Am. L. Inst. 1934) $\$ 439$.

136 Seckerson v. Sinclair (1913) 24 N. D. 625,140 N. W. 239; Oulighan v. Butler, supra note 133.

137 Stone v. Dickinson (1862) 5 Allen (Mass.) 29, $81 \mathrm{Am}$. Dec. 727; Ellis v. Howard (1845) 17 Vt. 330; Vose v. Woods (1882) 26 Hun. (N. Y.) 486; Allison v. Hobbs (1901) 96 Me. 26, 51 Atl. 245. Contra: Livesay v. First Nat. Bank of Denver (1906) 36 Colo. 526, 86 Pac. 102.

There is no joint liability if separate writs are executed at different times Sparkman v. Swift (1886) 81 Ala. 231, 8 So. 160; or where one becomes a lien on real property, the other on personalty. Miller v. Beck (Iowa 1897) $72 \mathrm{~N}$. W. 553, aff'd (1899) 108 Iowa 575, 79 N. W. 344.

138 Freshwater v. Bulner Rayon Co. [1933] Ch. 162.

139 McGannon v. Chicago \& N. W. Ry. Co. (1924) 160 Minn. 143, 199 N. W. 894.

140 Albrecht v. St. Hedwig's Roman Catholic Benevolent Soc. (1919) 205 Mich. 395, 171 N. W. 461. Cf. Foster v. Bussey (1906) 132 Iowa 640, 109 N. W. 1105.

On the same basis, successive acts of conversion are, in contemplation of law, several torts, although each converter is liable for the entire value of the property. Nicoll v. Glennie (1813) 1 Maule \& S. 588; Hopkins v. Hersey (1841) 20 Me. 449. Cf. Martin v. Golden (1902) 180 Mass. 549, 62 N. E. 977 (assault and false imprisonment). 
sufficient reason for holding a defendant liable for damages with which he had no connection. ${ }^{141}$ The basis for division is there; it is only the evidence which is lacking. The difficulty is no greater than in cases where the plaimtiff's own conduct has aggravated an injury caused by another. ${ }^{142}$ Each is held liable for his several share of the damages; but the difficulty of apportioninent offers a strong argument in favor of joinder in one action.

It has already been suggested ${ }^{143}$ that there are cases where the first tort-feasor may be liable for the damages caused by the second, smce he created the risk, but that the converse does not follow. This is true particularly where an injury inflicted by an original wrongdoer is aggravated by the negligent treatment of a physician. ${ }^{144} \mathrm{~A}$ release to the former should release the latter if there has been full compensation for both injuries, ${ }^{145}$ but not otherwise, ${ }^{146}$ and if there has been such full compensation, there should be indemnity against the doctor. ${ }^{147}$

G. Damage of the same kind, which it is difficult to apportion. A very similar problem is presented where the defendants, acting independently,

141 Albrecht v. St. Hedwig's Roman Catholic Benevolent Soc., supra note 140; La Bella v. Brown (1926) 103 N. J. L. 491, 493, 133 Atl. 82, 918; Viou v. BrooksScanlon Lumber Co. (1906) 99 Minn. 97, 108 N. W. 891.

142 Viou v. Brooks-Scanlon Lumber Co., supra note 141, citing Louisville, N. A. \& C. Ry. Co. v. Falvey (1885) 104 Ind. 409, 3 N. E. 389, 4 N. E. 908 ; Keyes v. City (1899) 107 Iowa 509, 78 N. W. 227; Chicago v. Meech (1896) 163 Ill. 305, 45 N. E. 290; Fullerton v. Fordyce (1897) 144 Mo. 519, 44 S. W. 1053; Throckmorton v. Missouri K. \& T. Ry. Co. (1896) 14 Tex. Civ. App. 222, 39 S. W. 174; Strudgeon v. Village (1895) 107 Micl. 496,65 N. W. 616.

143 See text at notes $46-48$.

144 See Notes (1929) 29 CoL. L. Rev. 630; (1933) 18 CoRN. L. Q. 257.

145 Smith v. Mann (1931) 184 Minn. 485, 239 N. W. 223; Retelle v. Sullivan (1927) 191 Wis. 576,211 N. W. 756.

146 Pederson v. Eppard (1930) 181 Minn. 47, 231 N. W. 393 ; Notes (1929) 29

Cot. L. REv. 630 (1933) 18 CoRN. L. Q. 257.

Compare Noll v. Nugent (1934) 214 Wis. 204,252 N. W. 574, where the original wrongdoer was released before the malpractice occurred.

It lias been lield that the receipt of payments under the workmen's compensation act will bar a subsequent action for malpractice. Polucha v. Landes (1930) 60 N. D. 159, 233 N. W. 264; McDonougl v. National Hospital Ass'n (1930) 134 Or. 451, 294 Pac. 351; Ross v. Erickson Construction Co. (1916) 89 Wash. 634, 155 Pac. 153, L. R. A. 1916F 319; Vatalaro v. Thomas (1928) 262 Mass. 383, 160 N. E. 269. To the contrary are White v. Matthews (1927) 221 App. Div. 551, 224 N. Y. S. 559; Viita v. Fleming (1916) 132 Minn. 128, 155 N. W. 1077; Smith v. Golden State Hospital (1931) 111 Cal. App. 667, 296 Pac. 127; Pedigo \& Pedigo v. Croom (Tex. Civ. App. 1931) $37 \mathrm{~S}$. W. (2d) 1074. The latter view seems clearly preferable, since the compensation act covers only loss of earning power; and other elements of damage, such as physical suffering and mental anguisl, may remain uncompensated. It would seem, however, that the payments received might be considered in reduction of damages against the plysician. See Hoehn v. Schenck (1927) 221 App. Div. 371, 223 N. Y. S. 418; but see Berkholz v. Benepe (1922) 153 Minn. 335, 190 N. W. 800 . 269.

147 Fisher v. Milwaukee Elec. Ry. \& Light Co. (1920) 173 Wis. 57, 180 N. W. 
do similar acts which result in damage of the same kind. If two defendants separately shoot the plaintiff at the same time, and one wounds him in the arm and the other in the leg, the ultimate result may be a badly damaged plaintiff in the hospital; but it is still possible, in theory at least, to separate the wrongs. ${ }^{148}$ Mere coincidence in time does not make one defendant liable for the damage inflicted by the other, nor does similarity of design or conduct, without concert. ${ }^{149}$ Evidence may be lacking upon which to apportion the medical expenses, or plaintiff's physical suffering, but this does not mean that each must be liable for both torts.

There are a number of similar situations, in some of which the extent of the separate torts is almost incapable of any definite proof. In the absence of statute, ${ }^{150}$ the owners of dogs which together kill sheep, ${ }^{151}$ or of trespassing cattle, ${ }^{152}$ are held liable only for the separate damage done by their own animals, unless there has been some concerted action, such as keeping the cattle in a common herd. ${ }^{153}$ Defendants who independently

${ }^{148}$ Le Laurin v. Murray (1905) 75 Ark. 232, 87 S. W. 131 (simultaneous independent assaults); Schafer v. Ostmann (1910) 148 Mo. App. 644, 129 S. W. 63 (same).

Distinguish the case where the victim dies, and the injury is not capable of apportionment. See Wilson v. State, supra note 134.

149 Dickson v. Yates (1922) 194 Iowa 910, 188 N. W. 948 (assault and trespass to property, committed at the same time by different groups). Cf. Millard v. Miller (1907) 39 Colo. 103, 88 Pac. 845, where the defendants independently appropriated different parts of plaimtiff's pasture.

150 In a number of states, owners of dogs which kill sheep are made liable for the entire damage by statute. Dale v. Hardinger (1917) 204 Ill. App. 640; Worcester County v. Ashworth (1893) 160 Mass. 186, 35 N. E. 773 ; McAdams v. Sutton (1873) 24 Ohio St. 333; Kerr v. O'Connor (1869) 63 Pa. 341; Remele v. Donahue (1882) 54 Vt. 555.

161 Russell v. Tomlinson and Hawkins (1817) 2 Conn. 206; Denny v. Correll (1857) 9 Ind. 72 (". . . because, as it would seem, one might be a big, and the other a little dog.") ; Anderson v. Halverson (1904) 126 Iowa 125, 101 N. W. 781; Buddington v. Shearer (1838) 20 Pick. (Mass.) 477; Nohre v. Wright (1906) 98 Minn. 477, 108 N. W. 865, 8 Ann. Cas. 1071; King v. Ruth (1924) 136 Miss 377, 101 So. 500 (damage done by trespassing dogs); Miller v. Prough (1920) 203 Mo. App. 413, 221 S. W. 150; State v. Wood (1896) 59 N. J. L. 112, 35 Atl. 654 (damage done by trespassing dogs); Van Steenburgh and Gray v. Tobias (1837) 17 Wend. (N. Y.) 562, 31 Am. Dec. 310; Stine v. McShane (1927) 55 N. D. 745, 214 N. W. 906 ; Dyer v. Hutchins (1889) 87 Tenn. 198, 10 S. W. 194; Adams v. Hall and Cootwire (1829) 2 Vt. 9,19 Am. Dec. 690.

The House of Lords recently departed abruptly froin this rule in Arneil v. Peterson [1931] A. C. 560. The earlier case of Piper v. Winnifrith (1917) 34 T. L. R. 108 was distinguished upon the ground that there was no evidence that tbe dogs worked together.

152 Dooley v. Seventeen Thousand and Five Hundred Head of Sheep (1894) 4 Cal. Unrep. 479, 35 Pac. 1011; Westgate v, Carr (1867) 43 Ill. 450; Cogswell v. Murphy (1877) 46 Iowa 44; Powers v. Kindt (1874) 13 Kan. 74; Wood v. Snider (1907) 187 N. Y. 28,79 N. E. 859 ; Pacific Live Stock Co. v. Murray (1904) 45 Or. 103, 76 Pac. 1079.

153 Ushirohira v. Stuckey (1921) 52 Cal. App. 526, 199 Pac 339 ; Ozburn v. Adams (1873) $70 \mathrm{IIl}$. 291; Montgomery v. Handy (1884) 62 Miss. 16; Wilson v. White (1906) 77 Neb. 351, 109 N. W. 367, 12 Am. St. Rep. 852; Jack v. Hudnall 
pollute the same stream, ${ }^{154}$ or who flood the plaintiff's land from separate sources, ${ }^{155}$ are only liable severally for the damages individually caused, and the same is true as to nuisances due to noise, ${ }^{156}$ or pollution of the air. ${ }^{167}$ Perhaps the most extreme example is the case of separate repetitions of the same defamatory statement, ${ }^{158}$ or separate acts which result in alienation of affections. ${ }^{159}$

(1874) 25 Ohio St. 255, 18 Am. Rep. 298. Cf. Stephens v. Schadler (1919) $182 \mathrm{Ky}$. 833, 207 S. W. 704 (dogs kept together).

154 Jones v. Tennessee Coal, Iron \& R. R. Co. (1918) 202 Ala. 381, 80 So. 463 ; Symmes v. Prairie Pebble Phosphate Co. (1913) 66 Fla. 27, 63 So. 1; Standard Phosphate Co. v. Lunn (1913) 66 Fla. 220, 63 So. 429; Thomas v. Ohio Coal Co. (1916) $199 \mathrm{Il}$. App. 50; City of Valparaiso v. Moffit (1895) 12 Ind. App. 250, 39 N. E. 909, 54 Am. St. Rep. 522; Bowman v. Humphrey (1904) 124 Iowa 744, 100 N. W. 854; Watson v. Pyramid Oil Co. (1923) $198 \mathrm{Ky} .135,248$ S. W. 227 ; Johnson v. City of Fairmont (1933) 188 Minn. 451, 247 N. W. 572; Masonite Corp. v. Burnham (1933) 164 Miss. 840, 146 So. 292; Martinowsky v. City of Hanmibal (1889) 35 Mo. App. 70; Watson v. Colusa-Parrot Mim. \& Sm. Co. (1905) 31 Mont. 513, 79 Pac. 14; Chipman v. Palmer (1879) 77 N. Y. 51, 33 Am. Rep. 566; City of Mansfield v. Brister (1907) 76 Ohio St. 270, 81 N. E. 631; Little Schuylkill Nav. Co. v. Richards' Adm'r (1868) $57 \mathrm{~Pa}$. St. 142, $98 \mathrm{Am}$. Dec. 209; Seely v. Alden (1869) 61 Pa. St. 302, 100 Am. Dec. 642; Gallagher v. Kemmerer (1891) 144 Pa. 509, 22 Atl. 970; Sun Oil Co. v. Robicheaux (Tex. Comm. App. 1930) 23 S. W. (2d) 713; Pulaski Anthracite Coal Co. v. Gibboney Sand Bar Co. (1909) 110 Va. 444, 66 S. E. 73 ; Farley v. Crystal Coal \& Coke Co. (1920) 85 W. Va. 595, 102 S. E. 265, 9 A. L. R. 933; Mitchell Realty Co. v. City of West Allis (1924) 184 Wis. 352, 199 N. W. 390.

155 Miller v. Highland Ditch Co. (1891) 87 Cal. 430, 25 Pac. 550, 22 Am. St. Rep. 254; Keyes v. Little York Gold Washing Co. (1879) 53 Cal. 724; Ryan Gulch Reservoir Co. v. Swartz (1925) 77 Colo. 60, 234 Pac. 1059; Sellick v. Hall (1879) 47 Conn. 260; Verheyen v. Dewey (1915) 27 Idaho 1, 146 Pac. 1116; Chicago \& Alton R. R. Co. v. Glinney (1886) 118 Ill. 487, 9 N. E. 203; William Tackaberry Co. v. Sioux City Service Co. (1911) 154 Iowa 358, 132 N. W. 945, 134 N. W. 1064, 40 L. R. A. (N. s.) 102, Ann. Cas. 1914A, 1276; Polk v. mlinois Cent. R. R. Co. (1917) 175 Ky. 762, 195 S. W. 129; Sloggy v. Dilworth (1888) 38 Minn. 179, 36 N. W. 451, 8 Am. St. Rep. 656; Blaisdell v. Stephens (1879) 14 Nev. 17, 33 Am. Rep. 523; Boulger v. Northern Pac. Ry. Co. (1918) 41 N. D. 316, 171 N. W. 632 ; Sun Co. v. Wyatt (1908) 48 Tex. Civ. App. 349, 107 S. W. 934.

150 Shernan Gas \& Elec. Co. v. Belden (1909) 103 Tex. 59, 123 S. W. 119; Neville v. Mitchell (1902) 28 Tex. Civ. App. 86, 66 S. W. 579; Munday v. South Met. Elec. Light Co. (1913) 29 T. L. R. 346.

157 Key v. Armour Fertilizer Works (1916) 18 Ga. App. 472, 89 S. E. 593 ; Swain v. Tennessee Copper Co. (1903) 111 Tenn. 430, 78 S. W. 93.

158 Smith Bros. \& Co. v. W. C. Agee \& Co. (1912) 178 Ala. 627 , 59 So. 647; Yocum v. Husted (1918) 185 Iowa 119, 167 N. W. 663; Howe v. Bradstreet Co. (1911) $135 \mathrm{Ga} .564,69 \mathrm{~S}$. E. 1082 ; Webb v. Cecil and Vaughan (1848) $48 \mathrm{Ky} .198$, 48 Ain. Dec. 423; McGee v. Collins (1924) 156 La. 291, 100 So. 430, 34 A. L. R. 336; Harriott v. Phimpton (1896) 166 Mass. 585, 41 N. E. 992; Rice v. McAdams (1908) 149 N. C. 29,62 S. E. 774; Blake v. Smith (1896) 19 R. I. 476, 34 Atl. 995; Bebout v. Pense (1913) 31 S. D. 619, 141 N. W. 515; Hall v. Frankel (1924) 183 Wis. 247, 197 N. W. 820; Pope v. Hawtrey (1901) 17 T. L. R. 717.

There may be joint liability for defamation where the parties bave acted in concert. Davis v. Hearst (1911) 160 Cal. 143, 116 Pac. 530; Green v. Davies (1905) 182 N. Y. 499,75 N. E. 536.

159 Barton v. Barton (1906) 119 Mo. App. 507, 94 S. W. 574; Heisler v. Heisler (1911) 151 Iowa 503, 131 N. W. 676. 
The difficulty of assessing separate damages has received frequent mention in these cases, but it is not regarded as sufficient justification for entire liability. The emphasis is placed upon the theoretical possibility of apportionment, and the fact that each defendant has caused a separate invasion of the plaintiff's interests. ${ }^{100}$ There has been some criticism of this result, and it has been urged ${ }^{161}$ that each tort-feasor be held liable for the entire loss, or at least that the burden of proof be placed upon the defendants as to their separate responsibility. A few courts, upon one ground or another, have held each clefendant liable for the entire amount. ${ }^{162}$

It seems reasonable to say that this difficulty of proof has been overstated. The courts necessarily have been very liberal in awarding damages where the uncertainty as to their extent results from the nature of the

160 Distinguish the cases where the acts of the defendants have resulted in a single, theoretically indivisible invasion. Folsoin v. Apple River Log-Driving Co. (1877) 41 Wis. 602 (streain obstructed by dam of one defendant and bridge of the other, flooding plaintiff's land); Northrup v. Eakes, supra note 126 (streain polluted with oil, which was ignited and burned plaintiff's property); Weingand v. City of North Platte (1922) 108 Neb. 17, 187 N. W. 90 (obstructing sewers, which backed up into plaintiff's hotel). In such cases both wrongdoers were necessary to the single result, and neither alone would have caused any damage.

161 Wigmore, Joint Tortfeasors and Severance of Damages (1923) 17 IrL. L. REv. 458.

As is pointed out in the note in (1931) 19 CALIF. L. REv. 630, there is some precedent for shifting the burden of proof. A defendant who wilfully confuses goods of another with his own must prove which goods are his, or the court will award all to the plaintiff. Stone v. Marshall Oil Co. (1904) 208 Pa. St. 85, 57 Atl. 183, 65 L. R. A. 218, 101 Am. St. Rep. 904.

And it was held in Armory v. Delamirie (1722) 1 Stra. 505, that the defendant would be liable for the most costly stone which would fit plaintiff's ring, unless he showed the true value of the one taken. In Yatter v. Mathies (1930) 139 Misc. $26,246 \mathrm{~N}$. Y. S. 548 , the court shifted the burden of proof to defendants, one or more of whom had lost goods in transit.

162 Moses v. Town of Morganton (1926) 192 N. C. 102, 133 S. E. 421, held defendants who had polluted a stream jointly lable, upon the ground that each had knowledge of the other's activities, which was called concert.

In West Muncie Strawboard Co. v. Slack (1904) 164 Ind. 21, 72 N. E. 879, it was held that there was joint liability for pollution, upon the ground that a public nuisance had been created, and the welfare of the coinmunity demanded the result. There seems to be little sense in this idea, and it was repudiated in City of Mansfield v. Brister (1907) 76 Ohio St. 270, 81 N. E. 631; Mitchell Realty Co. v. City of West Allis (1924) 184 Wis. 352, 199 N. W. 390.

Selby Oil \& Gas Co. v. Rogers (1923) 94 Okla. 269, 221 Pac. 1012, and Avery v. Wallace (1924) 98 Okla. 155, 224 Pac. 515, rely upon Northrup v. Eakes, supra note 126 , where the dainage was clearly indivisible.

In Johnson v. Thomas Irvine Lumber Co. (1913) 75 Wash. 539, 135 Pac. 217; Goldstein v. Tunick (1908) 59 Misc. 516, 110 N. Y. S. 905, it was held that there was entire liability hecause there was a "single injury;" and McDaniel v. City of Cherryvale (1913) 91 Kan. 40, 136 Pac. 899 said that the wrongdoing was "concurrent." 
wrong itself. ${ }^{163}$ It has been said that no very exact proof will be required, and that general evidence as to the proportion in which the defendants contributed to the result will be sufficient to support separate verdicts. ${ }^{184}$ As a last resort, in the absence of anything to the contrary, it may be presumed that the defendants are equally responsible, and the damages may be divided equally between them. ${ }^{105}$ Apart from the procedural technicalities cast in his way, there are surprisingly few cases in which the plaintiff has definitely been denied recovery for lack of proof. ${ }^{166}$ The difficulty is certainly no greater than in cases where part of the damage is to be attributed to the plaintiff himself. ${ }^{167}$

All of these cases point rather definitely to the conclusion that the test of entire liability is the absence of any logical basis for apportionment of the damages. If any such basis exists, and the court can say definitely that separate portions of the loss are to be attributed to each individual defendant, then neither is liable for what the other has caused. Difficulty of proof does not impose liability upon either, but it is met to some extent by giving the jury a comparatively free hand. The chief obstacle to plaintiff's recovery is the unreasonable refusal to permit joinder of the defendants $\mathrm{m}$ one action, with the accompanying danger that each will succeed in blaming the entire loss upon the other.

H. Acts innocent in themselves which together cause damage. Thus far it has been assumed that the conduct of each defendant is wrongful in itself. A more troublesome question arises where the acts of each, standing alone, would not be wrongful because they would cause no damage. If several defendants independently pollute a stream, the impurities traceable to each may be negligible and harmless, but all together may render the water entirely unfit for use. The difficulty lies in the fact that each defendant alone would have committed no tort. There would have been no negligence, and no nuisance, since the use of the stream would have been a reasonable one, and no harm would have resulted. May acts, then, which singly would be lawful, become tortious because of their concurrence?

163 Little Schuylkill Nav. Co. v. Richards' Adm'r, supra note 154; Columbus v. Rohr (1907) 30 Ohio C. C. 155; and see McCorarrex, Damages (1935) 102.

104 Eckman v. Lehigh \& Wilkes-Barre Coal Co. (1912) $50 \mathrm{~Pa}$. Super. 427; Miller v. Prough (1920) 203 Mo. App. 413, 221 S. W. 159; William Tackaberry Co. v. Sioux City Service Co., supra note 155; Hill v. Chappel Bros (1933) 93 Mont. 92, 18 P. (2d) 1106.

165 Wood v. Snider (1907) 187 N. Y. 28, 79 N. E. 858; Buddington v. Shearer (1838) 20 Pick. (Mass.) 477; Powers v. Kindt (1874) 13 Kan. 61; Partenheimer v. Van Order (1855) 20 Barb. (N. Y.) 479; Anderson v. Halverson (1904) 126 Iowa 125, 101 N. W. 781; Miller v. Prough (1920) 203 Mo. App. 413, 221 S. W. 159. 108 One such case is Slater v. Pacific American Oil Co. (1931) 212 Cal. 648, 300 Pac. 31. 167 Cf. Walters v. Prairie Oil \& Gas Co. (1922) 85 Okla. 77, 204 Pac. 906. 
Obviously the plaintiff's interests have been invaded, and if each defendant is to escape upon the ground that his contribution was harmless in itself, there will be no remedy. ${ }^{168}$ There is authority to the effect that acts which individually would be innocent may be wrongful when they combine to cause damage. ${ }^{169}$ The explanation of the paradox is that the standard of reasonable conduct applicable to each defendant is governed by the surrounding circumstances, including the activities of other defendants. Pollution of a stream to even a slight extent becomes unreasonable when similar pollution by others approaches the danger point. ${ }^{170}$

168 "Where there is a large number of persons mining on a small stream, if each should deteriorate the water a little, altliough the injury from the act of one might be small, the combined result of the acts of all miglit render the water utterly unfit for further use; and if each could successfully defend an action on the ground that his act alone did not materially affect the water, the prior appropriator miglit be deprived of its use, and at the same time be without a remedy." Hill v. Smith (1867) 32 Cal. 166.

169 "The amount of obstruction caused by any one of them might not, if .it stood alone, be sufficient to give any ground of complaint, thougl the amount caused by them all may be a serious injury. Suppose one person leaves a wheelbarrow standing on a way, that may cause no appreciable inconvenience, but if a liundred do so, that may cause a serious imconvenience, which a person entitled to the use of the way lias a right to prevent; and it is no defense to any one person among the hundred to say that what he does causes of itself no damage to the complainant." James, L. J., in Thorpe v. Brumfitt (1873) L. R. 8 Cl. App. 650. Cf. Lambton v. Mellish [1874] $3 \mathrm{Ch} .163$.

Similar statements are found in Hillunan v. Newington (1880) 57 Cal. 56; Woodland v. Portneuf Marsh Valley Irr. Co. (1915) 26 Idaho 789, 146 Pac. 1106; Blair v. Deakin (1887) 57 L. T. (N. s.) 522 ; Delaware \& Hudson Canal Co. v. Torrey (1859) $33 \mathrm{~Pa} .143$; West Muncie Strawboard Co. v. Slack, supra note 162; United States v. Luce (C. C. Del. 1905) 141 Fed. 385, 411; and cf. Northrup v. Eakes, supra note 126; Tidal Oil Co. v. Pease (1931) 153 Okla. 137, 5 P. (2d) 389. Contra, Gay v. State (1891) 90 Tenn. 645.

170 "The extent to which the appellee has contributed to the nuisance may be slight and scarcely appreciable. Standing alone, it miglit well be tbat it would only very slightly, if at all, prove a source of annoyance. And so it miglit be, as to each of the other numerous persons contributing to the nuisance. Eacli standing alone miglit amount to little or nothing. But it is when all are united together, and contribute to a common result, that they become inportant as factors, in producing the mischief complained of. And it may only be after, from year to year, the number of contributors to the injury has greatly increased, that sufficient disturbance of the appellant's rights has been caused to justify a complaint. One drop of poison in a person's cup may liave no mjurious effect. But when a dozen, or twenty, or fifty each put in a drop, fatal results may follow. It would not do to say that neitler was to be lield responsible. In that state of facts, as in the one presentcd by this case, each element of contributive injury is a part of one common whole, and, to stop the inischief of the whole, eacl part in detail must be arrested and removed." Woodyear v. Schaefer (1881) 57 Md. 1, 40 Am. Rep. 419.

Cf. Parker v. American Woolen Co. (1907) 195 Mass. 591, 81 N. E. 468, 10 I. R. A. (N. s.) 584; Lawton v. Herrick (1910) 83 Conn. 417, 76 Atl. 986; Weidman Silk Dyeing Co. v. East Jersey Water Co. (1914) 85 N. J. L. 432, 91 Atl. 338. Compare the case suggested in Blair v. Deakin, supra note 169, of two manufacturers each discharging a clemical harmless in itself, which combined with the other causes a pollution. 
The privilege of making use of the water is limited by the possibility of harm to the plaintiff, in view of the fact that other defendants make similar use. The single act becoines wrongful because of what others are doing.

The problem is really one of whether the privilege to make use of property, or to carry on activities, is absolute or relative. The decisions imposing liability afford a powerful argument against the existence of any "natural right," and in favor of the "reasonable use" doctrine in nuisance cases.

It would seem, however, that there can be no tortious conduct unless the individual defendant knows, or at least has reason to know, that his conduct may concur with that of others to cause injury. ${ }^{171}$ The point apparently has received little consideration. Likewise, since most of the cases have arisen in equity, there has been no discussion of a possible apportionment of damages. The Idaho court ${ }^{172}$ has said that liability is several, as in the case where each defendant does separate damage.

I. Alternative liability. If two defendants negligently shoot across a public highway at the same time, and plaintiff is struck by one shot, which might have been fired from either gun, it is clear that one defendant has caused the injury, but the other has not. In such cases, the courts have shown some eagerness to find concert of action on the part of the defendants, and so permit recovery agaimst both. ${ }^{173}$ In the absence of such concert, the rule has been very definite, that the plaintiff must plead and prove his case against one or the other, and may not join thein in the alternative. ${ }^{174}$

The hardship upon the innocent plaintiff in such cases has led to the suggestion $^{175}$ that the burden of proof be shifted to the defendants. Where the culpability of both defendants is clear, and it is only causation which

171 In Lambton v. Mellish, supra note 169 , Chitty, J. laid considerable stress upon the fact that each organ-player was aware of what the other was doing, as a basis for holding their conduct tortious. Compare Folsoin v. Apple River Log-Driving Co. (1877) 41 Wis. 602 , where the instruction approved is that the defendant dam company would be liable, provided that it had notice of the bridge obstruction. Also McKay v. Southern Bell Tel. \& Tel. Co. (1896) 111 Ala. 337, 19 So. 695, 31 L. R. A. 589.

172 Woodland v. Portneuf Marsh Valley Irr. Co. (1915) 26 Idaho 789, 146 Pac. 1106.

173 Oliver v. Miles (1927) 144 Miss. 852 , 110 So. 666 ; Benson v. Ross (1906) 143 Mich 452, 106 N. W. 1120; cf. Regina v. Salmon (1880) 6 Q. B. D. 79; State v. Newberg (1929) 129 Or. 564, 278 Pac. 568.

174 Oglesby's Sureties v. State (1889) 73 Tex. 658, 11 S. W. 873; Casey Pure Milk Co. v. Booth Fisheries Co. (1913) 124 Minn. 117, 144 N. W. 450,51 L. R. A. (N. S.) 640; Hartzell v. Bank of Murray (1925) 211 Ky. 263, 277 S. W. 270; see Cohn-Baer-Myers \& Aronson Co. v. Realty Transfer Co. (1907) 117 App. Div. 215,102 N. Y. S. 122 , aff'd (1908) 191 N. Y. 533,84 N. E. 1110.

175 Carpenter, Workable Rules for Determining Proximate Cause (1932) 20

Cartr. L. Rev. 396, at 406. 
is in doubt, this seems an eminently desirable procedure; but where there is no evidence as to where culpability lies, the hardship may be equally great upon an innocent defendant. ${ }^{176}$ In England, and in a few states, statutes have specifically authorized joinder of parties in the alternative. ${ }^{177}$ It has been held that such statutes do not make the liability joint for purposes of removal to the federal courts, ${ }^{178}$ but that they do aid the plaintiff to the extent of enabling him to make out a prima facie case against both defendants by proving that one or the other must be liable. ${ }^{170}$ Apparently this means that each will be liable for the full damages in the absence of further evidence.

The conclusion to be drawn from this grouping of the cases would seem to be, that a tort is "joint," in the sense which the American courts have given to the word, when no logical basis can be found for apportionment of the damages between the defendants. The question is whether, upon the facts, it is possible to say that each defendant is responsible for a separate portion of the loss sustained. The distinction is one between injuries which are capable of being divided, and injuries which are not. If two defendants, struggling for a single gun, succeed in shooting the plaintiff, there is no reasonable basis for dividing the injury, and the tort is joint. If they shoot him independently, with separate guns, and he dies, the tort is still joint, for death cannot be apportioned. If they merely inflict separate wounds, and he survives, a basis for division exists, no matter how difficult the proof may be, and the torts are several..$^{180}$ If two defendants each pollute a streain with oil, it is possible to say that

176 Compare the suggestion of WIGMORE, SELECT CASES OF THE LAW OF TORTS (1912) § 153, quoted in the note (1931) 19 CALIF L. REv. 630 at 637: "When two or more persons by their acts are possibly the sole cause of a harm, or when two or more acts of the same person are possibly the sole cause, and the plaintiff has introduced evidence that the one of the two persons, or the one of the same person's two acts, is culpable, then the defendant has the burden of proving that the other person, or his other act, was the sole cause of the harm." (Italics ours).

177 English Rules, O. 16, r. 4; Cal. Code Civ. Proc. \$§ 378, 379 (a) ; Irl. Rev. Stat. (1935) c. 110, §§ 151, 152; 2 N. J. Comp. Stat. (Cum. Supp. 1911-1924) §§ 163280, 163-282; N. Y. Civ. Prac. ACt (1935) §§ 209, 211. Cf. Conn. Prac. Book (1922) p. 278, § 155; R. I. Gen. Laws 1923, \& 4368; Wis. Stat. (1921) \& 2603; PrEiminary Draft, Proposed Rules of Civil Procedure for Federat Courts (1936), Rule 27. 725.

${ }^{178}$ Lynch v. Springfield Fire \& Marine Ins. Co. (E. D. N. Y. 1926) 15 F. (2d)

179 Hummerstone v. Leary [1921] 2 K. B. 664; Thermoid Rubber Co. v. Baird Rubber \& Trading Co. (Sup. Ct. Trial Term 1925) 124 Misc. 774, 209 N. Y. S. 277; S. \& C. Clothing Co. v. United States Trucking Corp. (1926) 216 App. Div. 482, 215 N. Y. S. 349.

180 Counpare Le Laurin v. Murray, supra note 148, and Schafer v. Ostmann, supra note 148 (simultaneous independent assaults) with Wilson v. State, sulpra note 134; Thompson v. Louisville \& Nashville R. R. Co., supra note 134; People v. Lewis, supra note 134 '(death). 
each has interfered to a separate extent with plaintiff's rights in the water, and to attempt some rough apportionment of the damages; it is not possible if the oil is ignited, and burns the plaintiff's barn. ${ }^{181}$ Entire liability is imposed only where there is no reasonable alternative. ${ }^{182}$

But in all of these cases, there are obvious procedural advantages in joinder of the parties in one action. It is a narrow, legalistic view which refuses to allow joinder because the loss can be apportioned. It is equally unreasonable to hold that, because joinder is permitted, there must be entire liability, a release to one must be a release to all, and there can be no contribution or indemnity. It is as foolish to deny joinder because of substantive rights, as to change substantive rights because of joinder. In the law of torts, substance and procedure were once husband and wife; but surely the day has come when that marriage has been dissolved.

William L. Prosser.

ScHOOL OF LAW,

UNIVERSTTY OF MTNNESOTA

181 Compare Watson v. Pyramid Oil Co. (1923) 198 Ky. 135, 248 S. W. 227; Sun Oil Co. v. Robicheaux (Tex. Com. App. 1930) 23 S. W. (2d) 713, with Northrup v. Eakes, supra note 126.

182 An excellent analysis of the problem, apparently arriving at this conclusion, is found in the recent case of Golden v. Lerch Bros. (Minn. 1937) ........ N.W.

Plaintiff was employed, in buildings where he was exposed to silica dust, by defendant partners from 1917 to 1929, and by defendant corporation from August 8, 1929 , to January 31,1930 . In 1933 it was first ascertained that plaintiff had developed silicosis. There was medical testimony to the effect that silicosis is the cumulative result of successive inhalations of the dust, which is harmless up to the poimt where the body can no longer eliminate it. It was held that all the defendants were properly joined in one action, and that each was liable for the entire damages. Peterson, J., rested the decision upon the ground that there was a single injury, and no basis upon which it could be assigned in parts to the respective wrongdoers. The decision distinguisbes the case of McGannon v. Chicago \& N. W. Ry. Co., supra note 31, which is not easily distinguishable upon its facts, upon the ground that there a distinct injury resulted to the plaimtiff while he was employed by each defendant. 